University of Louisville

ThinkIR: The University of Louisville's Institutional Repository

Electronic Theses and Dissertations

1939

\title{
The opium problem.
}

Jack Thompson

University of Louisville

Follow this and additional works at: https://ir.library.louisville.edu/etd

Part of the History Commons

\section{Recommended Citation}

Thompson, Jack, "The opium problem." (1939). Electronic Theses and Dissertations. Paper 1949.

https://doi.org/10.18297/etd/1949

This Master's Thesis is brought to you for free and open access by ThinkIR: The University of Louisville's Institutional Repository. It has been accepted for inclusion in Electronic Theses and Dissertations by an authorized administrator of ThinkIR: The University of Louisville's Institutional Repository. This title appears here courtesy of the author, who has retained all other copyrights. For more information, please contact thinkir@louisville.edu. 


\title{
UNIVRRSITY ON IOUISVIITE
}

THE OPIUI PROBLTAI

\author{
A Dissertation \\ Subaitted to the Paculty \\ Of the Graduate Bchool of the \\ Univeraity of Louleville \\ In Partial Fulfillment of the \\ Requirements for the Degree \\ of Master of Arts
}

Department of Histiory

by

Jeck Thompson

Year

1939 
IFI: OPIUY PROBTEA

By

Jack Thompson

43869 
Hame of Student:

Title of Thesis: The Opinm Problem

Name of Director:

Approved by Reading Committee composed of the following members:

Representative of Inglish Department:

Date: $\frac{\text { Ley }}{4}$ /es9 
TABIE OF CONTENTS

CHAPTER

PAGE

1. THE ORIGIN OF THE DRUG PROBIEM

Prehistoric times; Greek and Romen references;

Biblical references; early Chinese history; first Chinese anti-opium edict; Indian opium; early English opium affairs; act of Commissioner Iin; opium wars; edict of Emperor Kiaking in 1800;

Warren Fastings in India.

2. ATTEMPTS TO CONTROL THE DRUG TRAFIIC PRIOR TO THE IRAGUE OF NATIONS

British Opium Act of 1878; British Society for the Suppression of Opium Trade in India; American Activitiea; Chinese Imperial Edict of 1906; Shanghai Conference; United States' Drug Lawa; Hague Conferences; period of the World War; China in 1917; conditions in 1920.

3. PREPARATION FOR THE OPIUM CONHERENCES

Versailles Treaty; Article 23 of the League; The Advisory Comittee on the Traffic in Cpium;

material gathered by the committee from 1920 to 1925; resolution calling for the two Geneva Opium conf erences.

4. THE FIRST OPIUI CONFERENCE

Assembly resolution; work of the conference; convention formed; China's withdrawal; lack of clarity in the draft calling for the conference; appraisal.

5. THE SECOND OPIUL CONTERENCE

Measures to be considered; Sub-Committees appointed; real work of the conference; competence of the conference; American proposals; publicity; America's withdrawal; convention formed; accomplishments. 
6. THE WORK OF THE OPIUN ADVISORY COMMITTEE SINCE THE GENEVA CONTEREMTES

Review of work before the conferences; functions since 1925; conditions in China and Persia; illicit traffic; import certificate plan; free ports and zones; black list; weak national administrative units; national monopolies adrocated; direct limitation; review and appraisal of its work.

7. THE ORIGIN AND WORK OF THE PERUANENT CENTRAL OPIUR BOARD

Reasons for its creation; difficulties in being established; its powers and functions; how it works; difficulties encountered; appraisal of work.

8. CONVENTION FOR IIMITING THE MANUTACTURE AND REGULATING THE DISTRIBUTION OF NARCOTIC DRUGS OF 1931

Background; need for limitation and regulation; tasks of the conference; terms of the convention; creation of Supervisory Body; accomplishments.

9. COMAISSION OF ENQUIRY INTO THE CONTROL OF OPIUN SMOKING IN THE FAR EAST

Reasons for appointing the commission; scope of its work; material gathered; conclusions reached.

10. PRTPARATIONS FOR A IIMITATION OF PRODUCTION CONHTREHCE

Why Iimitation of production is necessary; work of Preparatory Committee; raw opium production; objectives of proposed conference; need for a successful conference.

11. GENERAL SUMMARY AND CONCLUSION 
CHAPIIR I

THE ORIGIN OF THE DRUG PROBHHY 


\section{CHAPIRR I}

\section{THE ORIGIN OF THE DRUG PROBTHAI}

The ues of opium juice ae medicine has been know for many conturier, and in all probability dates back to prehistoric times. The carliest eources which give definite proof of the use of oplum are early Greek and Roman writings. The earliest trade reoord show that the traffic in opium existed in the Fax Fast before the time of the Crusades. Yany have ouppoed that the Igyptiane kew about the properties of opium, but their writings ohow no trace of this knowledge. The Arab tradero were the firat who were known to have been familiar with the drug called opium and thoy in tura introduce it into China. Acoording to some soholare, there is a reference to poppy julee in the Bible. In sereral passages In the Old Testament the word rosh is mentioned in connection with the word Ialnah, wormwood or abeenthe. I

"Rosh in these passages is in the authorized version rendered hemlock. Rosh, howerer, in Hebrew is the word for 'head', and so it has been taken by later scholari to mean poppy head, and me-rosh, rendered by Jowish interproters as 'poison-water,' is taken to mean the juloe of the poppy."2

Professor Bloomfield of the Sanskrit Department of

1. Jeremiah VIII 14, IX 14.

2. Macht, David I. "The History of Opium, " scientific American, Ney 29, 1915, pp. 350-52. 
Johns Hopking UnIVersity says that opium is now at home in India and that in the classical literature there is no mention of 1t. From the time of the Hogul conquest there appears a word khosh-khagh, meaning poppy seed, and khogh_khosh-resh. moaning the juice of the poppy. From the latter word we recognize our modern word haghilh. LBia uinor goemo to hare been the early home of opium, and from there it wae carried to Greece. It is not at all certain whether Hippoerates knew of opium, but some substance similar to opium was referred to by him. 1

At the beginning of the third contury B. C.. Theophrastus refere to opium as meconium; it appears to hare consisted of an extract of the whole plant. This is sometimes referred to a the first authentio acoount of opium.

'Soribonlus Iargus, in his 'Compositions Medicamentorum,' about the year forty of the present era, describes the mothod of procuring opiun from the capoulos of the poppy. and about the year serenty-seren of the same century Dioscordes makes a distinction between the juice of the capsules and the extract of the whole plant. From this we suppose that the collection of opium was rather important at this time." 2

The drug soon became rery popular in Rome and the shopkeepers took orer the trade. The coca plant was used by the Indians of South America for the same purpose as the poppy in the Far East. Many othar shrubs and plants were also used to get

1. Macht, Darid 1., loc. olt.

2. Ibid. 
narcotic drugs.

From the first to the twelfth centuries the opiun of Asia xinor appears to have been the only known to comerce. In the thirteenth century, opium io mentioned by simon Janueneis, phyoleian to Pope Hicholas IV. In the sixteenth century, opium is montioned by Pyree (1516) as a production of the kingdon of Cous (Kuch Behar, southwest of Bautan) in Bengal, and of Yalawa. ${ }^{2}$ The spread of Yohamedent an oeems to have cauged the opread of oplum to India. The Arabo introduced the drug into the Fast, at first into Peraia and later into China. Tho Arabie phystelan used opium rexy auah and wrote much about it. "The earliest mention of opium as a product of India is by the traveler Barbosa, in 1511." 2

The Arabs began trading with China around the ninth century. Iater, the Chinese began bringing the drug in themselves. But at that time it was used only as a modicine. The opium producing poppy is mentioned in Chinese literature early in the Tang dynasty (from A. D. 618), and tho medicinal use of its seeds is referred to in the "Herbalist's Treasury," composed in 973.3 Opium seems to have been knom in China for many years before it was used excessively for amoking. It appears that the smoking of opium was first introduced by

1. Encralopedia Britannica, 11th Ed., Vol. XX, p. 130.

2. IbId.

3. KOrse, H. B., The Internationel Relations of the Chinese p. 171. 
mixing it with tobecco. The Dutch indulged in the smoking of tobacco in Java and from there it opread to Formosa, thence to Amoy and the mainland generally. This was in the middle of the geventeenth century and thereafter the use of opium for amoking apread repidy. The spanish alded the Dutch in this enterprise by bringing with them from the Horth Americen continent to their Philippine posseseion much of the aarcotic known as tobacoo. Chinese traders took this tobacco back to the Chinese ports and it spread in this manner. ${ }^{I}$ The Chinese emperors, when they conquered Amoy and Formosa in 1683, first came Into contact with the problem of oplum smoking which, until well into the eighteenth century, was serious only in the district around Amoy. Opium traffic did not become a menace to the Oriental trader until it was developed by the Furopeans.

When Emperor Kenghi conquered Amoy and Formose in 1683, the Imperiel Government issued no deoree against opium, nor did the Bmperor eren revive the prohibition of his ancestors against tobacco smoking. It was left to his successor, Yung Cheng, to deal with the matter; and ho, in 1729 , six years after his succession, issued the first anti-opium edict, ordaining serere penalties against the sale of opium for moking and the opening of opium-smoking dirans, but no speoific penalties were prescribed for the smoker. It cannot

1 Ibid. p. 172. 
be doubted that the Chinese merchants entered into the traffic and shared in the great profits. Up to 1729 the opium imported into Chino was small and it came mostly from India. Foreign opium was first introduced into China by the Portuguese and later by the British Fast Indis Company. The Iast India Company got control of poppy cultivation in India in 1757 as a result of the vietory of Clire at Plasey. At this time the opium trade was mostly in the hands of the Portuguese and it remained so until 1773. In that year the East India company took control of it, and that is the earliest date of Inglish merchents importing opiun into China. The trade was left in private hands until 1780, when the company began their monopoly. At this date there began an enormous increase of foreign opium finding its way into china. In 1796 the emperor revired the penalties of 1729 , but this could not check the menace. Finally, in 1800 the Bmperor Kiaking issued an edict prohibiting the importation of opium from abroad, and the cultivation of the poppy at home. This ushered in the smuggling of opium which continues to the present day.

About this time the House of Commons in England decided that it was not a wise financial policy to give up such a valuable source of revenue as the opium trade to the Fast India Company. Since the government had come to look

1. Morse, H. B., op cit., p. 173. 
at the remunerative side of the traffic, naturaliy nothing was done to check 1t. This trade inereased until by 1837 there were 30,000 chests imported as compared to 4200 in 1796. 1 During this tine there was little attention paid to the decree of Emperor Kiaking and China made no stringent efforte to suppress the traffic. From 1821 to 1839 the forces agalnst optum did otrengthen some, culminating in the Opium Var. In 1837 the Chinese Government decided to stop the trade altogether. Whether alazmed at the trade or the drain of silver, Iin-Tre-8u, a high commissioner, was sent to Canton to check the illicit traffic.

Yuch of the work that had been done in the past $f e x$ years to put down the opium traffic in China was opposed by the tax collecting mandering. Since many of theos were getting rioh from the trade, fev probably had any desire to stop 1t. But IIn was a zealous official and when ho was sent to Canton in 1839 he was determined to fulfill his miseion. Just before his arrival, custom house officials had selzed several chests of opium and now he demanded that these chests be turned orer to him.

At this time the interests of fingland in China were in the hands of Charles Ell1ot. When Iin took the chests mentioned abore. Flliot was in Hacao but he hurried to Canton.

1. Talpole, Spenser, History of Englend, Vol. VI, pp. 194. 
He arrived and demonded that all of the Britioh traders turn orer their opium to him and he i $n$ turn banded it orer to Iin. This amounted to 20,283 chests. Por anhile tension was lessened, but on April 4, Iin required all merchants engaged in the opium trade to enter into a bond under which all ressels hereafter used for this service ahould be turned orer to the Chinese Goremmont and all persons conneoted with the trade would "suffer death at the hands of the celestial court."I This was promptiy refused by the Britieh and unexpectedly the cheste of opium were destrojed. Mlso Iin ordered all commeroial intereourse with the trader to be topped, and forbade anyone oupplying them with food. Some of the Chinese merchants were considerably in debt to the Britioh and now that the opium was destroyed matters became worse.

The House of Commons hed refused to interfere with the opium trade which amounted to from $1,000,000$ to $1,500,000$ pounds annually to the Indian Gorernment. 2 When Elliot took over the opium from the merchants, it was ralued at from $2,400,000$ to $4,800,000^{3}$ and he had promised to give them bonds on the Britioh Government for this value. Later he refused to give this bond and sent for Aukland, GovernorGeneral of India. For armed asolotance. As the summer went on, affairs became more acute and many saw that armod conflict was inevitable.

1. Ibld., p. 96.

2. Irid.

3. InId. 
On July 7 some English sailors landed near Hong-kong and in a riot that followed, a Chinaman, Iin-Wei-hi, was killed. The Chinese demanded the killer. Flliot gave a large compensation to the relatives of the slain man but this did not satisfy the Chines authoritios. Flliot then told the authorities that the killer had not been found and that he would be put on trial when captured. Supplies were cut off from the Britioh subjects and Captain Elliot declared the port and river of Canton blockaded. Some nogotiations occurred but these merely eased affairs at hand and did not stop the opium traffic which went on with prices gradually riaing.

The act of Commiseioner Iin may serve to explain the outbreak of hostilities between the two countries, but it was merely the immediate cause. No doubt the opium situation was such that a break was certain to come. In 1841 hootilities ceased, and a treaty, which did not eren mention the opium traffic, was draw up mainly by the English. Flliot proceeded to take Canton after the Chinese refused to accept the treaty, but instead of attacking the city he allowed It to pay a ransom which put it virtually under the control of the English. This act did not satisfy the Chinese or the Britiah sailors. At this period, Henry Pottinger replaced Flliot, ${ }^{l}$ and after some fighting and the destruction of four

1. Owen, David Edward, Britioh Opium Policy in China and India, p. 185 . 
Chinese war-junks, the Chinese agreed, in 1842, to sign a treaty. By this Treaty of Nanking the channels of trade were opened to all nations from which opium was not excluded, the treaty stating that the money demanded from the Chinese Government should be paid to the opium merchants who had suffered loss through the action of Commissioner Iin. The Chinese saw no other reason for the war than the opium traffic, yet the British demanded and received Hong-kong outright and five other ports were opened to the British trade while opium was hardiy mentioned. The Chinese were informed that they could regulate the trade according to their ow laws so long as those laws did not seriously conflict with the British interests.

Ireaties were made at the same time with the United States and France, but the opium problem was not settled by the war or by these treaties. While opium was passed over in silence in the documents which closed the dispute between England and China, the trade was expressly prohibited in the American treaty, and opium was designated as contraband in the tariff annexed to the forming part of the French treaty. 2 The opinion of the Chinese people, as a whole, seems to have been ppposed to the opium trade but this merely turned the trade into illicit channels. After the treaties, they made no new laws againgt it in the country and even started the

1. Bell and Woodhead, The China Yearbook, 1912, p. 77. 2. Morse, H. B., op. cit., pp. 316-17. 
production of opium. During this era the opium situation was as alarming in India as it was in China. The production and trade of the commodity was even greater in India and it was practically impossible to balance the budget of the Indian Gorernment without the revenue derived from opium. Until the beginning of the twentleth century, the only measures taken against the spread of drug addiction were those of the Chinese Government.

The British attitude toward opium in China was that nothing would be done to help enforce the Chinese laws, the enforcement of which was purely a Chinese matter. Iord Ashley in 1843 introduced a resolution in the Britioh Parliament to the effect that the opium trade should be suppressed as it was inconsistent with the honor and duty of a Christian kingdom to support such a trade; ${ }^{1}$ but this motion was witharawn after a motion for adjournment was made. In the last decade of the nineteenth century, a group in England headed by Joseph Alexander ${ }^{2}$ exerted its influence on Parliament to secure a change of its Indian opium policy. Through the influence of this group, there was a Royal Commission appointed to study the problem from the angle of revenue. The report of this Commission did not change the policy in India but instead sanctioned it. ${ }^{3}$

1. Owon, David Edward, op. cit., pp. 230-31.

2. Ibid.. p. 311 .

3. Ibid.. p. 319 . 
In America, public opinion was very much againgt the opium trade. Of course some Amerlcans took part in the importation of opiun into China, but as a whole the Americans were the only ones to support the Chinese in their prohibition of the trade.

Between 1842 and 1858 China continued her attempts to supprese the opium traffic, but many of the officials helped smuggle the drug into China or helped landowers deceive the govermment in their production of the commodity. The door to the trade was further opened by the Second Opium Nar of 1856-58, caused by an ingult to the British flag and an insult to a French missionary. By the Treaty of Tientsin in 1858,1 China was compelled to throw open $81 x$ more ports, to allow Buropeans to travel in the interior of China, to permit the opium trade, and to promise protection to Christian miseionaries. Thus we see in 1858 the admittance by China of opium as a legal article of commerce.

The consumption of opium in India dates probably from the sixteenth century, and a monopoly of the purchase of opium from the oultivators grew up in Blhar under the Hughal Impire. The Empire lost the monopoly during the anarchy of the eighteenth century, but it was carried on in practice by a ring of Patna merchants. When the Fast India Company

1. Bell and Woodhead, op. cit.. p. 78. 
assumed reaponsibility for the collection of the Bengal and Bihar revenues in 1765, Its oertents appropriated the monopoly for their ow private benefit, and the prevailing corruption continued. When Tarren Hastings was appointed GoremorGeneral of India in 1773 and given power to organize a syotem of government, he found himself compelled to take orer the opium monopoly. I At firet, the right to manufacture opium was farmed out, but in 1797 the Gorernment asgumed the monopoly of manufacture. Since the time of Warren Hastinga, the sale of opium to China has been a great source of revenue to India. The cultiration of the poppy was at first confined to Behar and Benares, and it had to be sold at a fixed price to the Gorernment. In Kalwa the soil is eapecially adapted to the raising of the poppy, but the India Company, wishing to protect its monopoly, would not allow any of the Malwe opium to go through the port of Bombay. This natureliy led to the exporting of 80 valuable an article of trade from other porta; so eventually it was allowed to pass through the port of Bombay if the trader possessed a license. By 1838 Halwa was exporting more opium to China than to Behar or Benares combined. 2

1. Owen, Dav1d Edward, op. cit., p. 22

2. Talpole, Spenser, op. cit.. F. 196. 
CHAPTER II

ATTEMPTS TO CONTROL THE DRUG TRAFTIC PRIOR TO THE

ITAGUE OF MATIONS 
ATPFAPTS TO CONTROL THE DRUG TRAFFIC PRIOR TO THE

\section{ITAGUE OF MATIOHS}

The three earliest attempts at the control of the oplum problem have been mentioned in the previous chapter. They were the edict issued by Yung Cheng in 1729, the reriving of this odict in 1796, and the ediot isoued by the Emperor Kiaking in 1800. Throughout most of British India, the cultiration of opium was regulated by an act of 1857 as amended in 1878 and 1911. Under this act a license must be secured before the poppy can be oultirated. 1180 the total area to be sown and the exact area was fixed by the Government from year to year.

The British Opium Act of 1878 prohibited the manufecture, posseseion, trensport, import, export, and sale of opium, except as permitted by rules framed under this act, and provide for the confiscation of any opium in regard to which an offense was comnitted. Officers were given the right of search and a man who had opium was considered evading the law until he was proved innocent. Iicenses, under government control, were required for buyers and vendors. The system was strictly controlled by a method of transport passes and the number of licensed shops in an area was limited to 1ts needs. Also a notification under the Sea Customs Act of 1878 limited the import in other cases in which it was legally allowed before this act was passed. 
As stated before, the Britioh Society for the Suppression of the Opium Trade in India under the leaderahip of Mr. Alexander had been able to get a commission of enquiry to examine the production and sale of Indian opium. This commission was busy for two years prepartng a seren volume report which was completed in 1895. The combasion found that a limit was set in all prorinoes on the amount of opium or preparations from opium that a person might buy. They found that opium was used extensirely as a modicine and in some provinces it had acquired a near religious sanction. The Indian army was a great user of opium but the comission decided that it would do great harm to cat out the use at once. In industry workmen were never turned of becsuse of their use of opium as it was used only moderately and very seldom excessively. One thing the commission brought out rery forcefully was that it would be rirtually imposaible to distinguish between medical and non-medical use and so it would be impractical at the time to issue prescriptions for opium. It was declared that it had not been necessary to limit the growth and manufacture of opium and that it would be imposing a severe penalty on the people of India to do so.

In the existing treaties with China, India agreed that the question of importation of Indian opium into China was settled satisfactorily with her. The commission's report was justified by the fact that in 1895 the per capita 
consumption in India was 27 grains whereas in 1920 it was slightly lese, being only 26 grains.l Although this commission did not improre the Indian situation, it did lead the way to further reforms. In 1906 Parliement decreed that the Indo-Chinese Opium Trade was indefensible and that measures should be taken to bring it to an end, whioh was a great departure from its former opinions on the subject. Consequently, Ingland oooperated with Chine in her opium problem until the time of the shanghai and Hague meetings, when new cooperative thods were instituted.

After the annexation of the Philippine Islands by the United states, American interest in the opium problem became greater. In 1905 a commiseion was appointed to investigate the methods used in other territories where the sale of opium was exterisire. The commission, after visiting Java, Cochin China, Straits Settlement, and rarious places in China, based 1ts report on a study of the humen characteristics of Oriental people and the conditions existing in the orient. The Japanese administration of Formosa furnished the best material because here the Japanese had tried, in a systematic way, to cure the people of the habit. Japan, at this time, appears to have regarded opium more as an evil than did other Orlental people, and when they got control of Formosa it was decided to stamp out the eril of opium smoking. The opium

1. Dixon, G. Graham, The Iruth About Indian Opium, pp. 2-4. 
monopoly was put in the hands of the government, the cultiration of the poppy was prevented and there was a system of control applied to all phases of the opium problem. Hospitals were set up where ohronic users might be given free treatment and much literature was circulated about the loland regarding the dire effects of the opiun habit. This eystem of control prompted the commission to make this statement, "Japan, wioh is a non-Christian country, is the only country rloited by the Commission where the opiu question is dealt with in its purely moral and social aspects." 1

So impresed was the commission with this oystem of control in Formosa that they roommended oimilar one for the Philippine Islands. It is as follows:

1. Opium and traffic in opium must be immediately made a government monopoly.

2. Prohibition, except for medical purposes, after three years.

3. Only licensees, who shall be males and over 21 years of age, shall be allowed to use opium until prohlbition goes into effect.

4. All vendors or dispensers of opium, except for medical purposes, shall be salaried officials of the government.

1. T905. pp. 5i3-15. 
5. Every effort shall be made

(a) to deter the young from contracting the habit by pointing out its evil effects and by legislation:

(b) to aid in caring for and curing those who manifest a desire to give up the habit, and

(c) to punish, and if necessary, to remove from the islands incorrigible offenders. ${ }^{1}$

Between 1900 and 1906 China tried to check the consumption of opium through progressive tariff and internal taxation. Texes were raised on native opium and much foreign opium was coming in. Later the British and the Chinese had an agreement whereby both native and foreign opium should be taxed the same. Because this increase in price resulted in much smuggling, in 1903 the authorities reduced the taxes in the highly taxed provinces and then imposed the same taxes on all. This was merely a forerunner of the Imperial Edict of 1906.

Many causes have been given for the Chinese Imperial Edict of 1906. The Anti-Opium League had done much to show how the use of opium lowered the social standing and ability of the people. The agitation in the Philippine Islands naturally spread to China, and seventeen of the provinces

I. Ibia. 
submitted a formel memorial to the throne to suppress the opium evil. The cause of this edict has nothing to do with the immense task it set forth and the worthy object it had in view. Thio otatement came from the throne:

"amokers of opium hare wasted their time, negleoted their enployment, spoiled their constitutione, ruined their households and as the Court is desirous of making China powerful, opium must disappear by the end of the decade at the rate of one-tenth per year. 1

This statement was otartling to the Chinese and to the world and naturally the first question was hor it was to be done. A provision for putting this edict into effect had been made. It wa made a s ubjeot to fine to raise opium and all amokers had to be licensed and their names published. The quantity used must be registered and it could not bo moked where it was bought. All offioials who used opium must quit immodiately or lose their positions, and all new officials were kept under watch four days before they were allowed to go to work. It was eotimated that $40 \%$ of the people used the drug. Those who were under sixty years of age were required to cut down their use not 1088 than $20 \%$ a year until they were freo of the habit. For those over sixty and to princes, nobles, etc. there was a milder program. Madicine to help the people rid themselves of the habit should be prepared and

1. Bell and Toodhead, op. c1t., p. 430-31. 
distributed.

China succeeded greatly in her work and England agreed with her in 1908 to check the export of the drug from India by 5100 chests a year, which was one-tenth. 1 This was to continue from January 1, 1908 , for three years. At that time, if China had fulfilled her share of the agreement, this annual restriotion would be renewed until the export would be ended. By 1910 reports ahowed that the production of opium in China had decreased considerably and the latter part of that year negotiations for the renewel of the 1908 agreement were made. Thio latter agreement, finally drawn up May 8, 1911, sacrificed $\$ 15,000,000$ of Indian revenue. The principal features of the agreement were as follows:

1. China shall annually diminish the production of opium proportionately with the Indian export until opium is extinguished in 1917.

2. Recognizing China's successful prohibition of the use of opium, Great Britain agrees that Indian importation into China shall cease earlier if native production ceases.

3. Indian opium shall not be conreyed into those provinces which furnish proofs of local suppression, providing that Shanghai and Canton are the last

1. Owen, Darid Edward, op. cit., p. 337. 
ports to be closed.

4. Great Britain shall be granted facilities for and right of investigating the diminution.

5. China shall have similar rights of investigating sales and packing of opium in India.

6. China is undertaking to levy a uniform tax on Chinese opium, so Great Britain agrees to a consolidated import tax on 350 taelol $^{l}$ per chest.

7. China shall forthwith remove the provincial restrictions up on the wholesale sale of Indian opium, and shall permit no further taxation at the port of entry, otherwise, Great Britain may suspend may suspend or terminate the agreement.

8. The Indian exports shall not exceed 30,600 chests In 1911, and shall be reduced by 5100 chests annually. These chests shall be numbered and sealed.

9. If at any time during this period it becomes necessary to amend this agreement it may be done by mutual consent of the two high contracting parties. 10. This agreement shall come into force on the date of elgnature. 2

1. Modification of the Chinese ounce, containing 525 grains of silver.

2. Bell and Woodhead, op. cit., pp. 441-43. 
In 1911 there was a revolt in Ching and she was not able to live up to her agreement but Great Britain said sho would do her share without regard to what Chine did. It was hard for China to carry out her part of the bargain, but when the Republie was firmly established in China there was a renewed effort to otamp out the poppy and more vigorous action was taken than under the monarehy. From the most authentic information arailable, it seems that the consumption and production of opium in China had practically ceased in 1913. In 1913 Indian exports were entirely stopped in accordance with the agreement, causing a 108 of more than $\$ 35,000,000$ to the Indian Goremment. Fevertheless, the action ended a very contentious oubject between Great Britain and China. In accordance with thio agreement, the legitimate foreign opium trade in China and the legitimate Cainese cultiration of optum came to an end on December 31, 1917. Actually, in 1917-1918 a revolution broke out in China and the cultivation of the poppy reappeared during the latter part of 1918.1

On the suggestion of Bishop Brent of the Philippine Islands, the United States took the initiatire in bringing about the appointment of an international commission to investigate the matters connected with the use and traffic in narcotic drugs. The commission was composed of delegates

1. Owen, David Edward, op. cit., p. 352. 
from China, Japan, Great Britain, France, Germany, Holland, Turkey and the United States. After the investigation, this commisaion met at Shanghai from February 1 to 26, 1909, with B1shop Brent presiding. This Shanghai Conference was the first general international recognition that had been given to the existence of the problem of adiction to manufactured drugs. The comission experienced difficult times getting anything tangible accomplished, as much material was lacking from China, but the results of its four weeks investigation and discussion were put forth in nine resolutions. Thio report gave a recognition of the "unswerving sincerity" of the Chinese laws regarding opium production and cultivation but it dirulged unmistakably the vaguenese of the central government's knowledge of the actual conditions in the provinces. Korphia pills were being ueed greatly as a result of the action againgt the growth of poppies so this substance demanded a special article concerning its sale and use. A gradual suppression of opium smoking was suggested with all governments concerned taking drastic steps to control the manufacture, sale, and distribution of morphine. Antiopium remedies that contained opium should be taken under control and each country with settlements in China should apply that country's pharmocy laws in 1ts settlements. It was deemed sufficient to hare only a national control of the drug situation at this time. 
While this conference was criticized by some as not having accomplished anything, a statement issued by the Department of state at Washington explained that the conference had been called only for the $p$ urpose of studying opium problems and discussing the best means of dealing with them, and that all of the governments were pleased with the outcome. At any rate there were eeveral norel features of this conference that were worth considering, namely:

1. The emphatic recognition of the sincerity of the Chinese Government in stopping the production and consumption of opium, which had previously been doubted in some quarters.

2. The need for international cooperation to prevent illicit traffic in the arugs in question, especially by controlling the production of raw opium.

3. The grave importance of controlling the manufacture, sole, and distribution of morphine as well as opium.

4. The recognition that other drugs, liable to similar abuse, required scientific investigation. ${ }^{1}$

When we consider the fact that this was the first international opium conference ever held, we cannot minimize 1ts importance and the work it accomplished. It heralded the awakening of the world to the realization of the menace of manufactured drugs. The members were not empowered

1. Bell and Woodhead, op. cit., p. 439-41. 
to draw up a convention, because the governments were not yet willing to submit themselves to any binding agreement. When the United States called the Shanghai Conference, It was said in many quarters that America should put her own house in order first. True enough, the laws in this country were not what they should have been. By the Act of February 23. 1887, the United States forbade the importation of nonmedical opium into this country by Chinese citizens, or its importation into China by American citizens. By the Act of February 14, 1902, the United States forbade the sale, except for medical purposes, of opium to natires of the Pacific Islands within a certain sphere. ${ }^{1}$

Certainly these laws did not bring American opium legislation up to date, but on February 9, 1909, there was an act passed to prohibit the importation into the United States of opium for other than medical purposes. This law improved feeling throughout the world towards the United States. The law stated that

"it shall be unlawful to import into the United States opium in any form or any preparation or derivative thereof: Provided, That opium and the preparation or derivative thereof, other than amoking opium or opium prepared for smoking, may be imported for medical purposes only, under regulatione which the secretary of the Treasury is hereby euthorized to prescribe, and when so imported shall be subject to the dutjes which are now or may hereafter be imposed by law. " 2

1. Willoughby, W. W. Opium as an International Problem, p. 571.

2. U.S.Statutes at Large, 60 th Congress 1907.09, V. 35 Part 1 , Pubilic Law日, 
Also a fine of from $\$ 50$ to $\$ 5000$, or imprisonment for any time not exceeding two years, or both were to be imposed on offenders. In the same Congress a bill was passed forbiding the selling of opium in the Pacific Islands with a fine attached for offenders. Also, $\$ 20,000$ was appropriated by the 60 th Congress to pay the expenses of the three representatives to the international opium conference. With this legislation, America could call the powers together for an international agreement and hold a straight face in doing oo.

In the same year of the Bhanghai Conference, the United states invited the nations interested in the opium question to come to The Hague and draw up some international treaty based on the work done at Shanghai. An exchange of views and recommendations was taken up at shanghai, but the Hague Convention was to bo empowered to agree upon the committee recommendations to comit the rarious countries to some definite policy. With thio view in mind, the United States Government sent a list of topics, which it proposed should be discussed at the conference, to the other countries. summarized briefly, these proposals included-

1. Regulations to control opium from production to use.

2. A Iimitation of ports through which it might be sent.

3. Notifications of amount shipped from one country 
to another.

4. Application of nation's pharmacy laws in Settlements in Chine.

5. Uniform provisions for penal lawe againgt of fenders.

6. Uniform identification marks on drugs.

7. Granting of permits to traffiekers.

8. Adriaability of an international comiseion to be intrusted with the carrying out of any international agreement concluded.

Various ouggestione regarding these provisions were made by the governments present, Great Britaid probably making the most important. The British proposal was to the ef fect that gorerments should take up such drugs as cocaine and morphine, In addition to opium, and take drastic measures to control these drugs. She also suggested that the convention be applied to mamufactured druge.

The powers met at the Hague on December 1, 1911, and held meetings until the 23rd of January, 1912. The Conrention formed consisted of twenty-fire articles dirided into six chaptere, the main provialons of which were:

chapter 1: To control the production and distribution of raw opium, to prevent export of ram opium to countries which prohibit 1ts entry, to mark packages for export containing more than fire kilograms of raw opium, and to permit export and import only by duly authorized persons. Chapter 11: By gradual oteps to suppress entirely the traffic in amoking opiun; and to prohibit export and import 'as soon 28 possiblo.'

Chapter 111: To restrict the menufacture, sale, and use 
of medicinal opium, morphine, cocaine, and their derivatives to strictly medical and l egitimate purposes.

Chapter IV: In conjunction with China, to take measures to prevent the influx of raw opium, smoking opium, and manufactured druge into that country for addiotion purposes.

Chapter V: To 'Examine the possibility' of enacting laws or regulation making it a penal of fense to be in illegal possession of rew opiun, prepared opium (amoking opium), morphine, cocaine, etc.; to exchange information as to the various preventive measures enacted within their own borders, and to provide statistics as to the rarious aspects of the drug trade." 1

Chapter VI: Bxplained the method of ratification, signatures and the coming into effect of the conrention. The representatives of the gorernments refused to include the proposal of the United States regarding an international commiseion.

Io doubt there were many flaws in this convention but there was some definite work accomplished. One author criticizes it because there was no definite time limit for the suppreseion and no certain amount to be reduced, and because only prepared opium was forbidden to be exported or imported while raw opium was not corered. 2 Some of these are mere contentions and the recommendations made by this convention should have had far reaching rosults if put into effect. At the close of the conference, twelve powers which

1. Foods, Arthur, Dangerous Druge, pp. 52-53.

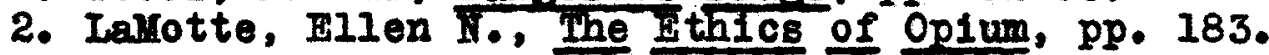


had participated in the drafting signed it, and thirty-four other powers were invited to sign. ${ }^{2}$

In Article 23, Paragraph 2, of the First Convention appear the following words:

"In the event of the signature of all the powers invited not having been obtained on the date of the 31st December, 1912, the Government of the Netherlands will immediately invite the powers who have signed by that date to appoint delegates to examine at The Hague the possibility of depositing their ratifications notwithstanding."

In accordance with this provision, the Government of the Netherlands called the meeting for July 1, 1913. In the Final Protocol of the Second International Opium Conference, it was decided that the deposit of the ratifications should now take place. Also several notes were sent to governments which had not signed, clearing up points that they had brought up. At the close of the Second Conference, thirty-four of the forty-six powers had signed the convention (twelve had not), while eight had either ratified or were disposed to do 80.2 The Third Opium Conference was called in accordance with the third resolution of the second Conference, which was

"That should the signature of all the powers invited in accordance with Paragraph 1 of Article 23 not be obtained by the 31st December, 1913, the Government of the

1. Willoughby, W. W., op. cit., p. 39.

2. Ibid. 
Netherlands will immediately request the signatory powers to appoint delegates to proceed to The Hague eo examine into the possibility of putting into effect the International opium Convention of the 22nd January, 1912."

At this conference it was decided that it was possible to bring into operation the Convention of 1912, although some powers had not yet signed.

The Convention came into force according to the Third Conference on December 1, 1914. At the end of this conference, forty-four of the forty-six powers had signed, eleven had ratified, and fourteen more had promised to do so, while not one of the remaining nineteen had expressed any intention of not proceeding to put the convention into force. ${ }^{1}$ When the World War opened, not many countries had passed the legislation they had promised, and control of the drug traffic during and immediately after the war was lacking. This was a critical moment in the fight for limiting the drug evil because it was rery slight then in comparison to what it is today, but countries were slow in seeing that the drug situation should be internationalized. The war brought up more paramount issues that overshadowed the drug problem and really stimulated the drug industry to such an extent that when the war closed this industry was harder to check than ever before.

1. Willoughby, W. W. op. cit.. p. 39. 
Just prior to and during the World War, the United States strengthened its drug laws because arrests had show during the past few years that there were more drugs finding their way into this country. Penalties were made more serere and administrative features strengthened by an act, of January 17, 1914..$^{1}$ By another act ${ }^{2}$ passed on the same day, it was provided that every manufacturer of opium in the United States must be a citizen of this country, must give a bond of $\$ 100,000$ and keep an elaborate set of books for inspection at any time. By the Aot of Maroh 3, 1915, 3 the United States provided regulations for the practice of pharmacy and the sale of poisons and narcotic drugs in the consular districts of the United States in China. The Harrison Narcotic 1 ct 4 of 1914 made provision for the regulation, importation, manufacture, production, compounding and traffic in coca leaves, their salts and derivatives. Certain sections of the Revenue Act of $1918^{5}$ divided the dispensers of opium into fire classes and imposed a tax on each. These laws affect the control of the opium trade in the United States up to the time of the creation of the constitution of the League of Nations.

1. 38 st. I. 275.
2. 38 st. I. 277.
3. 38 st. I. 817.
4. 38 st. I. 785.
5. 40 st. I. I057.


As otated heretofore, the Third Opium Conference in its protocol provided that the Convention of 1912 should come into effect upon its ratification, in the aignatory countries, regardleas of the other powers. By the time the World War closed, the only countries which had signed this convention were the United States, China, The Netherlands, Honduras, Norway, Belgium, Iuxemburg, Sweden and Spain. The Netherlands Goverment, which had been acting as repository for these ratifications, proposed to the Peace Conference that the League of Nations take orer this task. In the Treaty of Versailles the following Article, No. 295, was inserted, the effect of which was to secure the ratification of the conrention by all the powers signatory to the treaty:

"Those of the High Contracting Parties who have not jet signed, or who have signed, but not yet ratified, the Opiun Conrention of 1912, agree to bring said Conrention into force, and for this purpose to enact the necessary legislation without delay and in any case within a period of twelve months from the coming into force of the present Treaty."

Furthermore, the powers agreed that ratification of this treaty should, in the case of the powers which had not yet ratified the Opium Convention, be deemed in all respects equiralent to the ratification of that convention and to the signature of the Special Protocol adopted by the Third Opium Conference in 1914 for bringing the said convention into force.

"For this purpose, the Government of the French Republic would comnunicate to the Government of the Netherlands a certified copy of the Protocol of the Deposit of Ratifi.. cations of the present Treaty and would invite the Gorernment of the Netherlands to accept and deposit the said 
certified copy a if $1 t$ were a deposit of ratifications of the Opium Conventipn and a signature of the Addition-

al Protocol of 1914."

Therefore, the Opium Conrention of 1912 did not come into effect generally until the Treaty of Versailles became effective January 10, 1920.

The Versailles Treaty accomplishod with one stroke of the pon that which the precoding eight yoare had failed to do, namely, the ratification of the Hague Conrention of 1912. Tho special paragraph quoted abore was put into the treaty and all states more or 1988 had to accept it. A treaty was necessery at the close of the war and it is a notable fact that there were many influential humanitarians among those present at the drafting of the treaty. These men saw, beyond the mere spolls of war, weaker humanity engulfed in the opium traffic and they were courageous enough to give added impetue to the morement toward controlling dangerous drugs by forcing all signers of the Versailles Treaty to become adherers to the Hague Convention.

1. See the Treaties of Peace with Austria (Article 247), Hungary (Article 230), Bulgaria (Article 174), Turkey (Article 280). 
CHLPIER III

PREPARATION FOR THE GENHYA CONTERENCE 
PREPARATION FOR THE GENEVA CONFERENGES

The World War proved a great setback to the opium situation as the more momentous issues of war pushed it into the background. When this conflict ended, it found no great adherence to the Hague Convention but it did find a great increase in the addiction to manufactured drugs which made some immediate action necessary. The Netherlands Government now suggested that the League of Nations be given general supervision over the execution of agreements with regard to traffic in opium in accordance with Article 23 of the Corenant. According to Article 23 of the League it is provided that:

"Subjeot to and in accordance with the proriaions of international conventions existing or hereafter to be agreed upon, the Hembers of the League, (a).......... (b) ........... (c) will entrust the League with the general supervision over the execution of agreements with regard to the traffic in women and children, and the traffic in opium and other dengerous drugs."

When the agenda for the first session of the League of Nations was prepared, Committee No. 2 of the League Assembly, which dealt with technical questions, was given this general supervilion accorded in section (c) above.

At the twenty-fourth Plenary Session of the First Assembly ${ }^{2}$ which met on December 15, 1920, "The Advisory Committee on the Traffic in Opium and Other Dangerous Drugs 3

1. Under the Hague Convention the Netherlands Government had. acted as a repository for ratifications to this Convention. 2. C. 77. H. 39. 1921. XI, p. 538 .

3. Hereafter referred to as Advisory Committee. 
was established. This aet of the Assembly marked the realization of a concept which had 1ts origin in 1912. At the Hague Convention, the United States had presented the idea of a permanent international organization to supervise the traffic in. dangerous drugs but it was too widely opposed at that time to get any consideration. During the course of ten years there were many politicel changes and now governments were beginning to realize the $v$ alue of internationalizing control of a field as rast as was the drug traffic. As has already been stated, The Versailles Treaty stated that all signatories should become members of the Hague Convention and this greatly aided in securing the ratification of that document. With this resoIution passed to appoint the Adrisory Committee, the next step was to appoint the members.

The membership of the committeel was to be eight in number, one appointed by each of the gorernments nemed in the Assembly resolution, i.e., China, France, Great Britain, Holland, India, Japan, Portugal, and Siam. The idea of special assessors was adopted, and instead of representatives from gorernments with a opecial interest in the trade, the council decided to appoint three assessors with a special and technical knowledge of the opium problem. It was understood that the Advisory Comnittee would be made up of people whose main

1. Composed of representatives of the principal drug manufacturing and opium growing countries. 
interest would be in representing their own gorernment, but these as86880rs were to hare special knowledge necessary for the position and present this from a non-national standpoint. At this time there seems to have been no thought of including on this comittee states with the direct interest of the manufactured drugs, Fngland and France only incidental$2 y$ being of this type and they with more interest in the opium problem in their territories.

The Adrisory Committee ${ }^{l}$ was immediately oet up and held its first meetings in 1921. Fight representatives from the countries nomed in the resolution ${ }^{2}$ were present and they elected M. W. G. Van Wettum of the Hetherlands, Chairman, and Sir Halcolm Delevingne, of Great Britain, Vice-Chairman. Thio was the first body ever created on an international scale suit. able to deal with the opium problem, and thus its failure or success would have a profound influence on future bodies of the same nature. This committee had to start from the very bottom of the problem and create its own foundation. In order to get some tangible information, it was decided to send out a questionnaire to all nations regarding their drug laws, regulations, and problems. The main work of the committee was to settle questions ariaing out of the application of the Hague

1. Its work is fully discussed in a later chapter.

2. China, Great Britain, France, Netherlands, India, Japan, Portugal, and siam. 
Conrention but it had no knowledge of $t$ hese questions. The real duties of the Advisory Committee were very ambiguous and this indefiniteness acted as a stumbling block in all of its actirities.

The fifth oeseion was a very important one because it laid the foundation for the First Opium Conference. By a Joint Resolution unanimously adopted by both Houses of Congress, and approved by the President of the United States on March 2, 1923, It was declared that the United States must do everything in its power to safeguard its people from dangerous drugs and that the United States must work with the other nations to combat this eril. This marked an important step in the United States and was a great departure from its old 1dea of staying aloof from the affairs of Europe and the rest of the world. It further marked the cooperation of the United States, more than ever before, in non-political matters. Resulting from this resolution, Hon. Stephen G. Porter of the House of Representatives, the Right Reverend Charles H. Brent, and Dr. Rupert Blue were sent to the fifth session of the committee in a consultative capacity.

The main work of the fifth session was the discussion of the proposals of the United States, as follows:

1. If the purpose of the Hague Convention is to be achiered according to its spirit and true intent, it must be recognized that the use of opium products for other than medicinal and scientific 
purposes is an abuse and not legitimate.

2. In order to prevent the abuse of these drugs, it

is necessary to exercise control of the produc-

tion of raw opium in such a manner that there will

be no ourplus arailable for non-medical and nonscientific purposes. ${ }^{2}$

After discussing at length the merits of the American proposal and asking many questions pertaining to it, the Advisory Committee adopted resolutions calling for the adoption, in principle, of this proposal, but with the following reservation as proposed by several governments:

"The use of prepared opium and the production, export and import of raw opium for that purpose are legitimate so long as that use 18 subject to and in accordance with the provisions of Chapter II of the Hague Convention. 12

The Advisery Comittee recommended the inviting of all countries raising or producing the plants furnishing drugs or manufacturing aruge uch as morphine, heroin, or cocaine, to the conference so that a method of limitation or reduction might be brought about from actual information from the delegates.

These proposals of the Advisory Comittee were adopted by the Assembly of the League of Hations on September 27, 1923, as is shown by the following text:

1. This is in substance the resolution made by Mr. Porter in the House of Representatives. U.S.Statutes at Large, V01.42,p.1431 2. C. 418. Y. 184. 1923. XI, p. 202. 
"The Acsembly approver the proposal of the Adribery Committee that the Governments concerned should be invited immediately to enter into negotiations with a view to the conclusion of an agreement as to the measures for giving effective application in the Far Eastern territories to Part II of the Convention and as to a reduction of the amount of raw opiun to be imported for the purpose of smoking in those territories where it is temporarily continued, and 28 the mossures which should be taken by the Gorernment of the Republic of China to bring about the suppression of the illegal production and use of opium in China, and requests the Council to invite those Governments to send representatives with plenipotentiary powers to a conference for the purpose and to report to the Council at the earlieat possible date. VI. The Assembly, haring noted with satisfaction that, in accordance with the hope expressed by the Assembly in 1922, the Adrisory Committee has reported that the information now arailable make it possible for the Gorernments concerned to exemine, with a view to the conclusion of an agreement, the question of the limitation of the amount of morphine, heroin or cocaine and their respective salts to be manufactured; of the limitation of the amounte of raw opium and $t$ he coca leaf to be imported for that purpose and for other medicinel and scientific purposes, and of the limitation of the production of raw opium and the coca leaf for export to the amount required for such medicinel or seientific purposes, requests the council, as a means of giring effect to the principals submitted by the representatires of the United States of America, and to the policy which the Ieague, on the recomendation of the Advisory Committee, has adopted, to invite the Gorermments concerned to send ropresentatives with plenipotentiary powers to a conference for this purpose, to be held, if possible, immediately after the conference mentioned in Resolution V.

The Assembly also suggests, for the consideration of the council, the advisability of enlarging this conference 80 as to include within its scope all countries which are members of the League, or parties to the Conrention of 1912, with a view to securing their adhesion to the principles that may be embodied in any agreement reached."I

In these resolutions of adoption, it will be noted that

1. League of Nations, Fourth Assembly, Fifteenth Plenary Heeting, p. 7 . 
the Assembly called for two conferences to be held but the relationship between the two was not clear. This became a cause of misunderstanding as is shown later in the conferences themselres. It was the idea of the British delegation and bitterly opposed by the United States and France. The First Conference according to Resolution $V$ was to make its report directly to the Council of the League but this was not true of the second Conference. It seems that a better plan would have been for the First Conference to report directly to the second but this was not the case. Also it was provided that the First Conference was to select its own president but the president of the second was selected by the League without coneulting the conference members. The Advisory Committee had recommended a conference of committee for informal discussion but the Assembly Resolutions called for them to be composed of representatives with plenipotentiary powers. Thus we can see that the conferences opened with misunderstandings as to their status and this was show repeatedly by the members in the various meetings. Much real work was hindered by this as will be shown in the two following chapters. 
CHAPTER IV

THE FIRST OPIUM CONFERENGE 


\section{THE FIRST OPIUM CONFERTHCE}

After the American proposals were accepted in principle, the next step was the issuing of a call for the conference to meet. In accordance with the resolution adopted by the Assembly, the Pirst Conference was called and held its first meeting on Norember 3, 1924. Before the first meeting a Preparatory Committee had met and formed an Agenda as follows:

1. Election of President and Vice-President, Officers of the Conference, and Commissions, Adoption of the Rules of Procodure, etc., etc.

2. (a) Examination and consideration of the present oituation in regard to the application by the Powers represented of Part II of the International Opium Convention of 1912 in their Far Eastern territories and of the difficulties. which have been encountered in giving effect to Part II;

(b) Consideration of the measures which can be taken to carry out more effectively the policy embodied in Part II of gradually suppressing the use of opium for smoking with special reference to the suggestions put forward for consideration in the second resolution adopted by the Opium Advisory Committee of the League of Nations at its meeting in Nay 1923, and (c) Preparation of a Convention to embody the measures which may be agreed upon by the Conference. 3. Consideration (a) of the present situation in China with regard to the production of opium in the neighboring territories; and (b) of the measures which might be suggested to the Government of the Chinese Republic for bringing about a suppression of the illegal production and use of opium in China." I

Inasmuch as the Chinese situation was one of the main issues of the conference, it was decided to invite China to send a representative. The original resolution had talked of the

1. League of Nations, First Opium Conference, p. 9 
"measures which should be taken by China" but the Agenda prepared for the conference went further and mentioned "measures which might be suggested to the Chinese Republic." The resolution calling for the conference had specified that representatives be sent with plenipotentiary powers but it soon became evident that many delegations were not thus endowed. Each delegation was allowed to make its own views public concerning any meeting held, but in the light of the fact that all comittee and sub-committee meetings were held in private and these reports given to the press only upon the rote of the committee, any statement from a delegation might not clear up the points discussed.

The conference decided to take up for consideration (a) the present situation in China with regard to the production of opium and its effects on the control of the use of opium in the neighboring territories, and (b) the measures which might be suggested to the Government of The Chinese Republic for bringing about a suppression of the illegal production and use of opium in China. ${ }^{1}$ These two topics were to be discussed simultaneously, one in the morning and the other in the afternoon.

As has been stated before, China had practically eliminated opium from her country by 1917, but immediately

1. Ibid. p. 15 
afterwards there was a renewing of the growth and trade of this commodity. For this reason the conference had decided to discuss the Chinese siturtion and to invite China to the conference. It was seen in the very beginning that this was a serious problem and the revival of this evil had affected not only China but other countries with colonies nearby. The illicit traffic was shown to be a grave problem and kept itgelf before the conference much of the time. China came out boldly in faror of controlling this trade in the best possible way and promised all the help that she could give. The Advisory Comittee presented statistics to show that there was much smuggling of opium into China because of her unsettled government, whereupon Dr. Sze, Chinese delegate, atated the following:

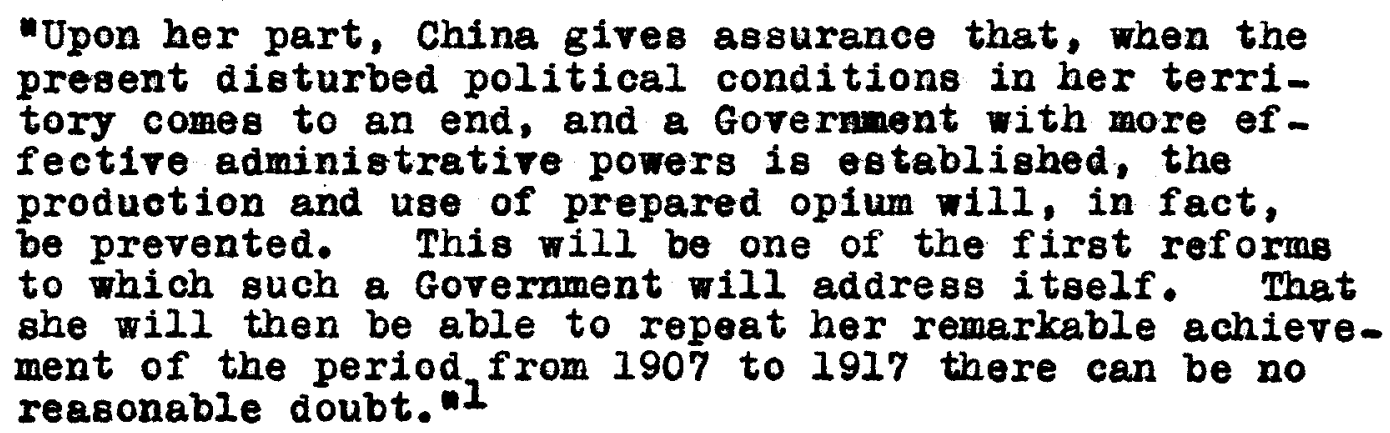

The Chinese delegation went further in stating that an intelligent and patriotic public opinion was being formed in China toward the reinforcement of the opium laws. China would not depart from her policy of absolute suppression and

1. Ibia.. p. 28 . 
would again show the world that she could adequately handle this enormous problem. True enough this illicit traffic was working havoc with some of her best methods, but the "disease that was paralyzing her normal activity" would be cured by applying rigidly the laws in force. The conference went on record as accepting China's statement of good faith in the matter.

With the Chinese situation disposed of, the conference next turned to the report of the subcomittee on the actual rates of conoumption of prepared opium in the different territories, the different systems of control of the use of opium in those territories and the question of contraband trade in opium. It was found that the contraband trade was so great that no estimate of it could be made and this added greatly to the number of smokers of opium. Since this trade existed to such an extent, the actual rates of consumption were indeterminate and no report could be made on them. The report showed many systems of control in use and although the committee was merely one of investigation, it suggested a government monopoly as the best method advisable under present conditions.

As regards the smuggling of opium, the committee said it would be impossible to stop the trade so long as there was such an enormous quantity of raw opium. Cooperation betreen governments in all phases of the illegal systems seemed to be the best method of checking this evil. The system of registration and rationing of smokers found most effective was 
that of the Japanese in the ialand of Formosa. Yet this system was so harsh that the comittee was skeptical of reccommending it for a large, congested area. This matter was dropped by the inclusion in the final text of the draft of a statement that the "Contracting Powers" should know that the system of registration and rationing of smokers had met success in some colonies and that they in turn should consider its adoption if they thought it feasible. These further provisions were accepted with minor changes in the final agreement of the conrention:

1. Except as provided with regard to retail shops, the importation, sale and distribution of opium shall be a monopoly of the Government and the right to import, sell or distribute opium shall not be leased, accorded or delegated to any persons whatever. 2. The preparation for ale of opium for smoking shall also be made a monopoly of the Gorernment as soon as circumstances permit.

3. (a) The system of employing persons paid by a fixed salary, and not by a commission on sele, for the retail sale and distribution of opium shall be applied experimentally in those districts where an effective supervision can be exercised by the adminlstrative authorities.

(b) Elsewhere the retail sale and distribution of opium shall be conducted only by persons licensed by the Government.

Paragraph (a) need not be applied if a system of licensing and rationing of smokers is in force which affords equivalent guarantees."Wl

unch discussion arose at the meetings between the British and Japanese delegations regarding the wording of the draft. Continually, the Japanese delegation held for

1. Ibid., Annex 13b, pp 160-62 
a strict iraft. In many instances this delegation was supported by China while France was the main ally of Great Britain. Finally, in practically every instance, the Britioh proposals were given precedence and they materially lowered the effectiveness that the conference might have assumed.

According to the final draft, the sale of opium to minors was prohibited and the number of rotail shops were to be limited. In order to get the opim problem before the people, it was urged that a disemination of literature be made through the schools. The suggestion was embodied in the draft that the export of opium, whether raw or prepared, and the transit through, or trans-shipment in, any posseseion or territory into which opium was imported for smoking ahould be prohibited. All contracting Powers should assist one another in ouppressing the evil, and furnishing information to the Secretariat of the League.

The protocol of the conference consisted of the main points already stated as suggestions by the subsomittee or parts of the final draft. Chine had aoked to be a member of the committee making the report, but she was refused memberghip and bhe resigned from the conference. This report was sent to the secretariat of the Ieague, as the conference was directed, Instead of to the Second Conference which had already started its meetings on November 17. The Protocol of the First Conference was signed at Geneva on February 11, 1925. 
The First Opium Conference completed a convention which was highly unsatisfactory to the countries which had hoped to have the legal smuggling of opium come to an end in a specified time. The conference did not assume any definite undertaking, and as stated abore, China withdrew. China had urged that profits from drugs be used for economic and moral betterment of the classes of people who used opium, and that financial considerations should not influence opium policies, but the other countries could not concur in this. The first conference did adopt an agreement strengthening Chapter II of the Hague Convention by providing that the importation, manufacture and distribution of opium should be made a state monopoly, with certain exceptions, by prohibiting the sale of opium to minors and by rarious other measures. The main points were put in a "Protocol" which was to bind the countries with opium-smoking territories to take stronger measures for the complete suppression of opium smoking in fifteen years. This period was to begin after the poppy growing countries had sufficlently checked the snuggling of opium, which was to be decided by a commission appointed by the League of Nations. Considering the amount of time consumed in meetings and the discussions held, the First Conference can be said to have accomplished very little of that which it was called to do. 


\section{CHAPTER V}

IHE SECOND OPIUN CONFERENCE 


\section{THE SECOND OPIUN CONTERENCE}

When the Seeond Conference met on November 17, 1924, the First Conference had completed, but not actually signed, a convention which was highly unsatigfactory. Some powers had hoped to see an agreement reached that would gire assurance that the legalized amuggling of opium would come to an end within a specified or reasonable period of time, but no such definite undertaking was assumed by the conference.

At the first meeting of the second Conference, the agenda as prepared by the League was presented. It was decided that discussions should be based on

"Consideration of the measures which can be taken to carry out the Opium Convention of 1912 with regard to:

1. A limitation of the amounts of morphine, heroin or cocaine and their respectire salts to be manufactured;

2. A limitation of the amounts of raw opium and the coce leaf to be imported for that purpose and for other medicinal and scientific purposes; and

3. A limitation of the production of raw opium and the coca leaf for export to the amount requifed for such medicinal and soientific purposes." 1

Inamuch as the First Conference failed to provide an effective means for the suppression of the traffic in prepared opium or failed to reach an agreement, Hon. Stephen Porter of the United States filed a reservation to the agenda to this effect and it was inserted in the record of the meeting.

1. C. 760. M. 260. 1924. XI, Vol 1, p 15 
After the adoption of the agenda, the President presented to the conferenee a list of the Draft Rules of Procedure as dram up by the Secretariat of the League. According to these rules, a Business Comittee was appointed which in turn had two general committees selected. The first of these was to take up the task of devising a scheme for the limitation of the amounts of morphine, heroin and cocaine to be manufactured, and the limitation of the production for export of raw materials from which these drugs are made, to the quantity required for medical and scientific purposes. I The second committee should consider the "revision of the Hague Convention which must necessarily follow on the adoption of any scheme for the limitation of the manufacture of the drugs, or the production of the raw materialo, or both." ${ }^{2}$ It wa further decided to appoint several sub-committees to deal with separate and indiridual subjects, and theso in turn were to report to the general groups. The sub-committees and the scope of their work were as follows:

Sub-Comnittee A. Suggestions for the limitation of the manufacture of aruga.

Sub-Committee B. Suggestions for the limitation of opium for export.

1. Ibid., p. 47 .

2. Ibid. 
Sub-Committee C. Suggestions for the limitation of the production of coca leaf for export.

Sub-Committee D. The foregoing suggestions from the point of consuming countries.

Sub-Committee $E$. Suggestions for the control of the international traffic more especially in regard to export, import, transshipment, etc., of opium, coca-leaves and dangerous drugs.

Sub-Committee F. Consideration of the report of the Health Committee of the League of Nations on the medical requirements for the drugs, and the material collected by the Preparatory Comittee and any other material that might be arailable with reference to the same question. This Comittee, it was declared, should be composed of medical, pharmaceutical and statistical experts. 1

In a report given by the Business Committee at the ninth meeting, a plan was presented for the division of the work between the two general committees. The measures suggested by the Adrisory Committee as a basis for the delibera-

1. Ibid., Annex 15, p. 455 . 
tions of the Second Conference were divided into three parts and it was decided that the first committee should consider those items falling in the first part and the second, those falling in the other two parts. These two general comittees each held four meetings before finally dissolving with very little accomplished, except that their reports served as bases for discussion on the subjects they covered. The real work of the conference was to consider the proposals from two sources: (a) Those made by the Advisory Committer of the League and contained in the Sixth Session report; and (b) those presented by the different delegations present at the conference. The American delegation, led by Mr. Porter, immediately proposed that the conference should consider the matter of the suppression of the legalized traffic in prepared opium in order that it might seek the solution of the opium problem which the First Conference had failed to find. This was immedately rejected by the British, Dutch, French and Portugese delegations but the majority of the delegations favored it. However, the ones opposing this resolution were the delegations from the countries within whose possessions that traffic actually existed. As a result of this prolonged discussion, the conference was adjourned from December 16 to January 12 and then by motion of the British delegation, it waited one week longer to renew the discussions. In this interval correspondence had been 
carried on with the home governments and the personnel of many delegations had changed.

The reason for all this debate on the competence of the second Conference to discuss prepared opium was that this item had been definitely given the First Conference. The delegations mentioned as being against the American proposal contended that their governments understood that the second Conference would discuss only narcotic drugs and not prepared or smoking opium and that they were not prepared to enter into discussions centering on the latter. The American delegation contended, that as the United States was not a member of the Hague Convention of 1912 nor the First Convention, that the American proposal to include the discussion of prepared opium in the Second Conference was legal.

When the conference re-convened, the discussions began anew. None of the delegations changed their statements and it seemed as though the conference was deadlocked when Dr. Sjostrand, of the Swediah delegation, made a motion that a mixed committee of sixteen, eight from each of the conferences, be created to see if some decision could be reached that would be acceptable to all delegations. Two protocols were prepared by this joint committee and these were accepted by Great Britain, France, The Netherlands, Portugal and India but they were rejected by the American delegation. This 
delegation contended that the protocols failed to fix a definite period within which the legalized traffic in prepared opium was to be brought to an end. M. Aguero, Cuban delegate, suggested that a small sub-committee be appointed, which was done, but it also failed to reach an agreement. As a result, the American and Chinese delegations withdrew from the conference. The points under consideration, which caused these withdrawals, were embodied in the protocol annexed to the convention which was drawn up by the Second Conference.

In its suggestions to the Second Conference, the first article as presented by the American delegation reads:

The Contracting Parties shall enact effective regulations for the control of the production and distribution of raw opium (unless laws or regulations on the subject are already in existence) and coca leares so that there will be no surplus available for purposes not strictly medical or scientific. The foregoing provisions shall not operate to prevent the production for exportation, or exportation, of raw opium for the purpose of making prepared opium into those territories where the use of prepared opium is atill temporarily permitted under Chapter II of this Convention (Hague), so long as such exportation is in conformity with the provisions of this Convention." I

In regard to this limitation of the production of opium and coca leaves, there was much divergence of opinion. The Italian delegation proposed that the American proposal

1. Ibid., p. 414. 
should be adopted with the right reserved to each state to except itself from its operation; or to provide that the control of the production of raw opium should be such that there would be no surplus arailable for export except for medicinal and scientific purposes. It was decided to refer this matter to a sub-comittee which reported 6 to 2 in faror of the United States suggestions. Howerer, two modifications were made; "the reference to coca leaves was deleted, and instead of 'the present Convention' in the last line but two, 'the Hague Convention of 1912' was mentioned"l and the following text was added:

"Further, any Contracting Party may declare, at the time of its signature of, or accession to, the present Convention, the limitations subject to which it accepts this article as regards the production and diatribution of raw opium. If such a declaration be made, the other Contracting Partiea agree that this article shall only apply in the case of the Contracting Party making the declaration, subject to the limitation contained in that declaration." 2

This aditional text and the American proposal were accepted.

"Thus the sum result of the long discussion on prepared opium was that the word and was substituted for the word or in Article 1 of the Hague Convention; the laws and regulations in execution of this article were to be periodically reviewed (no fixed period, however), and as required, strengthened; it was specifically provided that these laws and regulations were to apply to export as well as production and distribution (which, however, merely specifically stated what had been previously understood as implied); and finally, the provision of

1. Ibid., F. 247

2. Ibid. 
Article 3 was made applicable to coca leaves, which was not the case in the Hague Convention of 1912. surely a meagre result from such prolonged labors."

The subject of hashish and $i$ ts control by the present convention was presented at the sixteenth meeting of the conference. As this product was not included on the agenda, the decision was reached that the conference was not competent to deal with it, however, this subject was referred to subCommittee $F$. This product was studied still further and was reported on at the thirty-fourth meeting. It was added to those substances covered by the Second Convention, Chapter $V$, and illicit traffic in hashish and its resin was to be closely guarded against.

One of the subjects brought forward by the American delegation was that the production of coca leaves should be controlled so that there would be no surplus beyond that needed for medical and scientific needs. This was referred to Sub-Committee $C$ and the following report made:

'1. Article 2 of the Hague Convention of 1912 shall be extended to extend to coca leaves;

2. The system of import certificates and export authorizgtions shall be extended to apply to coca leaves." 2

Sub-Committee $E$ had to do with the control of the international traffic and it recomended that a strict

1. Willoughby, W. W., op. cit., p. 369

2. c. 760. 1. 260 . 1924. XI, p. 232 . 
authorization be made of all import and export certificates on each consignment and that each government issuing an export certificate should communicate this to the government to which the shipment was intended. It was further recommended that a strict licensing system be adopted, but the committee realized that much illegal traffic was carried on and in this spirit it adopted this text:

- The Contracting Parties will examine in the most farorable spirit the possibility of taking legislative measures to render punishable illegitimate transactions which are carried out in another country by a person residing within their territories."

Since Sub-Comittee $F$ was to deal with the medical requirements for the drugs under discussion, it reviewed the report of the Health Committee and fixed the legitimate requirements of opium at 450 milligrames per head and cocaine at seren. These needs were taken from reports from countries with highly developed medical assistance and it was understood that they could apply only to countries with similar conditions. This committee recommended that "no new product possessing habit-forming narcotic properties might either now or in the future be excluded from the provisions of the Convention." I In a special report concerning Indian hemp (hashish), the committee went of record favoring the use

1. Ibid., p. 314 . 
of this drug and the preparations derived therefrom only as authorized for medicel and scientific purposes.

Probably the greatest work of the Opium Conferences was the immense publicity resulting therefrom. This sounded a warning of the drug evil which was heard for many years all over the world. They added some, no doubt, to the Hague Convention and they established a Central Board to gather all information posaible on the drug situation. With all of the meetings, these conferences failed to do any of the three things they were colled to do, namely: 1. To limit to the world's medical and scientific needs the production of the raw materials from which narcotic habit-forming drugs are manufactured;

2. To bring to a speedy end legalized traffic in prepared opium; and

3. To control the international traffic in narcotic habit-forming arugs.

No agreement on the limitation of any of the raw materials was reached. The Hague Convention made no proTisions for the limitation of Indian hemp or coca leaves and these conferences failed to add to this. All that was done in regard to opium was the atatement in the

1. Discussed in detail in Chapter VII. 
Protocol of the Second Conference that the "Parties signatory to the present Protocol agree to take such measures as may be required to prevent completely, within five years from the present date, the smuggling of opium from constituting a serious obstacle to the effective suppression of the use of prepared opium in those territories where much use is temporarily." 1 The Council of the League of Nations was requested to appoint a commission to visit certain countries to find out the limitations and difficulties in those countries and report their advice as to the measures needed to limit the production of opium to the medical and scientific needs. No important adrance was made in the suppression of the use of prepared opium. The agreements of the second Conference in regard to international control, if carried out in good faith, ought to make easier the control of that vast amount of illicit international traffic in these drugs which now afflicts the nations of the world.

There was some feeling that the United States delegation should not have withdrawn from the conference. Inasmuch as this delegation was attending in an unofficial capacity only, its sitting no doubt added to the prestige of the countries favoring such a plan. The American plan was

1. C. 760. M. 260. 1924. XI., p. 523. 
under discussion and this delegation probably could have forced it to a vote by remaining. The main opposition came from the bloc controlling territories in the Far East and their main contention against the American plan was that no one controls China and when opium is suppressed in other colonies illicit opium will flow from China. However, the American delegation contended that it could not affix its signature to anything less than the American plan and that it could not get the ignature of the conference.

We can see that the relationship of the conferences was not clear and that they did not have reliable and sufficient data from which to get their information. Also, the nations concerned economically with the drug trade were reluctant to give it up and without their aid very little of an enduring nature could be accomplished. The most significant outcome of these conferences was that it set the world to thinking more about the dangerous drug problem and pared the way for more effective legialation in the future. 


\section{CHAPTER VI}

THE WORK OF THE OPIUM ADVISORY COMNITTEEE

SINGE THE GENEVA CONTERRIGRS 


\section{CHAPTER VI}

\section{THE WORK OF THE OPIUM ADVISORY COMMITTEE}

SINCE THE GENEVA CONFEREMCES

Beginning with the Hague Convention of 1912, there had been in the minds of earnest leaders in the fight againgt the drug evil the idea of some permanent central body to supervise the trade in dangerous drugs. However, no such body was created until the Advisory Committee on the "Traffic in Opium and other Dangerous Drugs" was establighed by a resolution ${ }^{l}$ of the First Assembly of the League of Nations on December $15,1920$.

The period during the World War saw such a spread of the opium menace that it caused nations to awaken and lend their support to some measure of control when the League was formed. Also, as has already been explained, the Versaillea Treaty provided that all signatories to that treaty would automatically become members of the Hague Convention of 1912. Previous to this maneuver very little success had been met in getting ratifications to the convention al though conferences had been held in 1913 and 1914 for this purpose. With the reference to the Hague Convention as given in the Versailles Treaty, a new era in drug control began.

1. C. 77 4. 39. 1921. XI, p. 538 . 
The origin, membership and early work of the Adrisory Committee have already been explained in Chapter 3. This chapter, therefore, will concern only the committee's work since 1925.

Immediately following the Genera Conferences, the most serious problem confronting the Advisory Comittee concerned the production of opium in China. All countries controlling territory in China were urged to make regulations and institute severe penalties for the breach of such regulations. Another important question was the export of opium from the Persian Gulf to the Far Fast. IlIicit traffic here was great and many schemes were discovered whereby drug edicts were eraded by ingenious methods. Many of the investigations carried on by the committee have concerned the Far Bast. Up to 1928 China had sent in only one annual report and Persia none. It oan be readily seen how hopeless the situation was without information gathered by the committee itself.

The problem of regulating the illicit traffic has been constantly confronting the comittee. Fach year statistics have been compiled that have thrown much light on the activities of the traffickers. It was found that there were huge financial resources back of the traffic and worldwide connections in the dispensing of the drugs. Several systems of control have been worked out but they have not proved 
entirely satisfactory. One system that has helped considerably was the import certificate plan. According to this plan, each government was to adopt a system of import certificates to be procured by the prospective importer of drugs from his government. These certificates were to be presented to the government of the exporting country before any export was permitted. One of the principal defects of this plan is the lack of an organ of central control. There was also no way of knowing the legitimate needs of countries and without this knowledge certificates could accompany orders and countries might still have excessive supplies. The Geneva Conference created a Permanent Central Board which would have some power to determine the legal requirement, but as show in Chapter 7, its powers were also limited. It was not until the Iimitation Convention of 1931 that any really reliable information on actual requirements was obtained. Since 1931. legal druge have been largely kept from the illicit traffic but clandestine factories have added greatly to it. The import certificate plan was a forerunner of better methods of gathering information.

In 1923 the Advisory Committee ${ }^{l}$ decided that much illicit traffic could be stopped if each country would communicate with other states concerned when seizures were made.

1. C. 72. Y. 27. 1923. XI., p. II. 
Summaries were to be sent to the Secretariat who made general sumaries and relayed the information to other countries. After this was done there was no central body to deal with the information but many interesting incidents came to light, one or two of which will illustrate the activities of the omugglers. A new method of sending narcotics from Switzerland was uncovered. Several shipments of clocks, shampoo powder, etc. were gent to China through certain banks there. When carefully examined, they were found to contain opium. In another case a band of international smugglers, found to be Russian emigrants, received many orders from the Far East. The checks came through London and Paris and the drugs came through Hamburg and Copenhagen. This one example shows how difficult such problems are to solve because so many countries are often involved.

In $1926 \mathrm{Sir}$ Malcolm-Deleninge of England expressed the opinion that such traffic could finally be brought to an end by a limitation on manufacturing and by stricter international control as provided by the Geneva Conference of 1925. ${ }^{1}$ This action was finally taken in the Limitation Conference of 1931 but it still failed to solve the problem.

In cases of seizures and captured traffickers, penalties dealt out were so low in many cases that they did not

1. C. 88 . M. 44.1925 . XI., pp. 503. 
deter criminals. The Far East was especially lax in this respect, although China in more recent times, has given the death penalty for such offences.

The Advibory Comittee became aware early in its work of the leakage of aruge into the illicit traffic through free ports and zones, and through its reports frequently called attention to this situation, it has never been able to get much control over these places. In 1930 a Black List was approved to let all countries know of those caught in the illicit trafic. Since the source of all arugs in this trade was not known, it was urged that a systemmatic and searching enquiry be made by all countries that manufactured druge. By using this method any country that really wanted to free itself of illegal drugs would know of all smugglers caught in other countries. Therefore it could keep on guard against the known criminala.

A much stricter control, based on more accurate and detailed information than had previously been received, was planned by the Adrisory Committee in 1930 when it prepared a new form for annual reports. ${ }^{1}$ The attempt of the committee to reach an estimate of the world's legitimate requirements from statistics had not met with success. Since

1. C. 138 . M. 51. 1930. XI., pp. 32-34. 
reports were not sent in, the committee asked the secretariat of the League to inrestigate the medical and scientific needs in various countries and thus give the committee some basis for operation. It could not fulfill the aims even of the Hague Convention without some fairly accurate estimate. Still, the laxity of national administrative oystems prevented the committee from getting anything like an accurate picture of the real needs of each state and little success attended this plan.

Probably the most important reason for the lack of success in these measures was the fact that most countries had no administrative units to deal with the drug problem. The Advisory Committee has repeatedly urged more suitable administrative machinery and has been responsible in a large measure for improved systems in many countries. The League Secretariat said unification of control was regarded as being of the greatest importance for efficient administration and direction of policy. All the information both on the national and international sides would be thus concentrated in a single department, and the delays and semi-paralysis which often follow on a divided authority would be aroided. ${ }^{1}$ Beginning in 1931 the committee began to note an improvement in cooperation from many countries and this greatly aided it in

1. C. 393. M. 1926. XI., p. 103. 
preparing better reports to present to the council. Awakening public opinion has caused some countries to get a monopoly of dangerous arugs for reasons of control instead of revenue. Nany modern proposals for coordinating drug control call for national and international monopoly. The opium monopoly for revenue had existed in India since the eighteenth century. Serious dificulties present themselves to governmente when they try to control drugs, but they must see that there are many advantages of control that will work for the improvement of the aituation.

The Convention of 1931 did not indicate that governments were to have monopolies but it did suggest that they consider the points in faror of such an arrangement. The opposition has come mainly from the fact that such a system of national monopoly would be difficult to administer and this same fact probably explains the reason for no system of control in many countries. Countries with large manufacturing concerns to deal with have generally opposed government monopolies, while those with practically no manufacturing have clamored for them. The power behind the drug industry is 80 great that the prospect of destroying it as a private enterprise, in favor of state monopoly, is one that most governments cannot face lightly. This one thing seems to have caused most govermments which manufacture drugs to oppose such a plan. It does have its difficulties no doubt, 
but so does the present system of laxity of control. vany dire effects upon mankind are caused by drugs of destruction being let 1008 in misdirected channels. The governments must be willing to accept more responsibility before they can get many results and for this reason the Advisory Committee has been working toward state monopolies.

The subject of direct limitation of drug production has been before the Advisory Committee intermittently since the committee was formed in 1920. But not unt1l 1929 was the problem considered serious. In that year the Assembly of the Ieague decided that the direct limitation of drug production was the basis for settling the drug problem. ${ }^{1}$ Since manufacturing countries were the only ones represented on the Advisory Committee until 1931, it was hard to get this committee to formulate any plan for a definite limitation of production. In that year seven newly appointed members from non-manufacturing countries were added and immediately the viewpoint of the committee began to change.

The committee has always had the idea that when the trade in drugs is brought under control that the manufacture will tend to limit itself to the legitimate needs. This was generally borne out in the first five years of the application of the Genera Convention, 1928-33. But in the mean.

1. This had been the central theme of the American proposals in 1923 but they were disregarded. 
time many clandestine factories had been opened which supplied the illicit traffickers with more drugs. The Assembly therefore requested the committee to consider some plan for the limitation of the production of dangerous drugs. It was decided that three fundamental points had to be considered; first, the quantity to be manufactured; second, the allocation of this amount among the present manufacturing countries; and third, the guarantee that all countries would receive their full requirements. 1

In the same session, the comittee adopted a plan to get eatimates and allocate world production to the manufacturing nations. This scheme rather farored the manufacturing countries which were members of the committee and did not take into consideration the feeling of the non-manufacturing countries towards such allocation of production. At the fourteenth session of the committee a draft was prepared for the Iimitation Conference of 1931.2 This was not supported by all of the members of the committee and remained a bone of contention during the conference. This disagreement was furthered in the Iimitation Conference but a plan superior to that presented by the committee was finally adopted. 3

1. C. 168. H. 62. 1931. XI., p. 4.

2. C. 115. 1931. XI. (Annex), pp. 242-5I.

3. This plan as adopted by the conference is discussed in detail in Chapter VIII. 
In view of the complicated nature of the drug problem and the fact that the Adrisory Committee was composed mainly of men with a national rather than an international point of view it is not difficult to see why so little has been done. The smugglers, traffickers, manufacturers, and addicts all present different problems. The means to carry out a good plan are arailable but the will to do so among the states that are committee members has been lacking.

It was decided in the Iimitation Convention to reduce manufacture, yet this is only secondary to limiting production of the raw materials. The comnittee was urged to make plans for the limitation of production, but it was not until 1932 that this topic was placed on the agenda and then only after much prodding by the Assembly. The United States' representative proposed that there be universal participation in a conference to limit production but little interest was show. Some countries agreed to the principle of limitation but either did not reply to a questionnaire in regard to production or said they could not limit it. Fepecially noted in the latter group was Bolivia, which produced enormous amounts of coca leares. The Bolivian gorernment stated that it could not undertake to limit production. Peru did not even reply. As a whole, the South American countries have never fully cooperated probably having been more delinquent than any other group in sending in reports. 
In reviewing the work of the Advisory Committee, we must bear in mind that many of its troubles existed before it began. It has never been very aggressive and has narrowly interpreted the principles upon which it was founded. Its members for the major part of its existence have represented manufeturing countries thus causing national isoues to predominate the discussions. The non-manufacturing countries were represented by assessors, but there were only three and their minority kept them from getting their views adopted. The committee has really accomplished very little in the nineteen years of its existence. From its first report to the Council to its very last one there is the same attitude that something more definite should be done about the drug problem but the committee feels that its scope of power is too narrow to permit it to accomplish that which should be done.

Some of its measures have been effective and in many instances it tried to regulate the drug traffic instead of attacking the more important issue of restricting its source. The import certificate plan stopped the open routes to the lllicit traffic, the black list supplied police with information about the illicit traffic and information on seizures helped get before the governments the actual conditions existing in various countries. All of these plans were good but no matter how well they worked they did not strike at the source. 
In general the representatives aerving on the committee were not picked according to qualifications and could not f11l the position with honor. The committee has no doubt been handicapped by lack of power but it seem that its greatest handicap has been a lack of responsibility to try to accomplish that which was in its power. The sovereign states have not been willing to give up their power to any committee. 


\section{CHAPTER VII}

THE ORIGIN AND WORK OF THE PERHANENT CENTRAI OPIUM BOARD 
CHAPTER VII

THE ORIGIN AND WORK OF THE PIRMANENT CENTRAI OPIUM BOARD

Probably the outatanding achierement of the Second Genera Opium Conference was the establishment of the Permanent Central Opium Board. The creation of this Board was the result of a compromise between those favoring and those opposing a plan of international control of the drug problem. The Opium Advisory Committee had been functioning since 1920 but it had never considered itself competent to carry out any authoritative program. 1 There was no doubt a need for some body with more power to help supervise the drug trade but until the time of the Second Opium Conference, the Advisory Committee had to do the best it could with 1ts limited powers. During the whole course of the discussion regarding the establishment of the Central Board, there was an interplay of differences of opinion and compromises. Only through the sheer determination of a few high minded individuals was the board able to be established with such powers as the separate nations would permit, yet with eren this limitation of powers, its creation showed conclusirely that the nations were beginning to realize that there was a more urgent need for drastic limitation of the drug trade.

1. See Chapter VI. 
A body known as the Opium Preparatory Committee was appointed by the council to draw up a draft convention to place before the conference when it met. In preparing this draft, many interesting attitudes regarding the opium question were brought to light by the various delegations. Much discussion arose regarding the American and British plan of direct control and the French view of indirect control. This comittee failed to return a unanimous opinion so two additional members were added. The committee then prepared the draft that was used for discussion by the Second Geneva Conference. This plan favored the French indirect control system but it went beyond this in calling for the creation of the Central Board. This board, like the direct limitation plan, met opposition from many delegations, the main argument being that such a body would trespass on the sovereign rights of individual states.

In its final form, the plan called for a Central Board to be made up of experts appointed by the Council on the advice of the Advisory Committee. The amounts of raw opium, coca leaves, or any of the substances derived from these that would be needed during the year was to be reported to this board. Furthermore, all governments should report quarterly on all imports, exports, and re-exports of each of the drugs, and semi-annualiy on the amounts manufactured and the stocks remaining with the wholesalers. Finally, at the 
end of each year a report was due on the amount of each drug consumed. If any country went beyond its quota, all others would be notified so that they would not send extra drugs into the particular country.

One of the main powers of the board was the right to furnish estimates for any country, even non-signatories, if the country furnished no estimate itself, or its estimate was too high. Any nation that felt that it should not have to stop shipping drugs to another might call a conference to discuss its merits in the case. As before mentioned, the idea of submitting the drug situation to international control met with many objections, some of which were brought out in the Genera Conference itself. ${ }^{1}$

After the conference met, six sub-comittees ${ }^{2}$ were appointed to deal with the various phases of the problem. Subcomittee $A^{3}$, on the limitation of the manufacture of drugs, at its first meeting, begen discussing the Central Board and trying to bring the direct and indirect control factions to some acceptable terms. Failing in this, the sub-committee appointed a Comittee of Fire ${ }^{4}$ which finally

1. C. 397 . H. 146. 1924. XI., p. 26 .

2. The subjects included under each of these sub-committees is given on pages $45-46$ of this paper.

3. Hade up of seven manufacturing countries and five others.

4. Composed of France, Great Britain, Japan, Netherlands, and the United States. 
reached an agreement but with many alterations to the plan of the Advisory Committee. The Advisory Committee had intended to create an organ of authority but this was replaced by one of general superrision.

In its new form the board was shorm of its power and its nature completely changed. Figures to be given the board were reduced and instead of $B$ etting each country'B estimates for consumption, manufacture and commerce, only estimates for medical and scientific use were to be reported. Egtimates were not to be binding and might be changed after the year had begun and the board had no power to decide on the legitimacy of an estimate or furnish one for a country that had failed to report. Offending countries could be asked for explanations but not boycotted. Only annual figures and not semi-annual, as proposed in the original plan, were to be given and government supplies were to be listed separately and not even discussed by the board. Since government supplies included raw opium in the Far East, this was an important exemption. The only improvement over the original measures was that statistics were to be furnished every two months instead of quarterly. ${ }^{1}$

From the Committee of Five the draft was returned to Sub-Committee A where France led in a fight to have the

1. C. 760. M. 260. 1924. XI., p. 119 . 
board shorn of its remaining power. This sub-comittee made only one improvement and that was ti have seizures reported annually with explanations. We can see that it was a very different plan for a Permanent Central Opium Board that was finally presented the Plenary Conference and accepted by the Second Geneva Opium Conference.

The plan for the Central Board was outlined in Chapter VI of the Second Geneva Conference but arguments regarding its power, finances and relation with the League were raised in the Council, Assembly and Advisory Committee. Finally it was agreed that the budget of the board should be included in that of the Ieague and thus it would have the prestige of being a part of the League. Also an interpretation was accepted that the board should have complete freedom from delay or interference from any other organ of the Ieague thus making it a completely independent organ regarding its technical competence.

The Central Board was set up as a body with more power to get action than the Advisory Committee had been able to get. The two bodies have worked together in a fairly mutual understanding, each going its own way independent of the other, not antagonistic, yet not overly cooperative.

One of the major tagks of the board has been the formation and improving of national systems of drug control and welding these together, as much as possible, into an 
international unit.

We have already noted that the Board was to collect statistics. This was one of the great tasks for it to accomplish, but this only atarted its work as it had to compile these statistics in such a way that they could be interpreted intelligently. The resulting figures had to be analyzed, annotated and used as the foundation from which the drug problem might be attacked. The main object was to find out the legitimate world need of various drugs and to discover, if possible, a way to reduce the output to these needB. This was a very difficult task as different climates, different continents, and different races presented very unlike situations. When the Board inquired into internal conditions to find the reasons for the differences, some countries objected. One example will suffice. The rest of the world outside Russia, Turkey and Japanese territories consumed only $620 \mathrm{~kg}$. of heroin in 1929, yet Japan consumed $1351 \mathrm{kgs}$. in the same period. The only explanation present. ed to the Board was that Japanese climate caused so many respiratory diseases that this much had to be used medicinally. Cough remedies required large quantities and practitioners used a lot of heroin because of arailability and price. Since there is no restriction against qualified persons prescribing preparations containing opium derivatives in Japan, this number is much larger than in other countries. 
The Board has worked out a system of grouping the countries into one of six divisions according to use, production, manufacture, etc., and this has been fairly satisfactory, yet it is only with the voluntary cooperation of all governments that the work can continue to be successful. In every meting some statistics are not arailable and thus all reports are incomplete. The report to the council of the statistios for 1929 contained the statement that the coming into effect of the Geneva Convention was having a beneficial effect on the drug situation throughout the world. This report showed a slight decrease in the amount of morphine converted, a decrease in the amount of cocaine manufactured, and a great decrease in the amount of diacetylmorphine produced. The final analysis of the report was to the effect that the board is concerned with countries which produce large quantities of raw materials for exporting and manufacturing. The report went further in suggesting that the board be given power to recommend against an offending country not only an embargo of exports to such country of the substances covered in the convention, but also of importa from that country. ${ }^{1}$

Accurate and complete statistical reports of the worldwide movement of narcotic drugs provide one of the

1. c. 241. M. 120, 2.930, XI., p. 10 
best regulatory devices, and the preparation of such reports is one of the main purposes of the board. Nany of the statiatical loopholes left in the Genera Convention were f1lled by the Iimitation Convention of 1931. It is interesting to note that gradually more countries send in statiotical reports yet in every report to the council there are many delinquencies which cause it to be incomplete. If the reports come in late it seriously hampers the work. The ever increasing degree of cooperation was noted by the board in its report to the Council for $1933 .{ }^{1}$ The report on the work in 1935 showed that in the world as a whole, the amounta of morphine, diacetylmorphine and cocaine manufactured in 1934 have fallen below any previous year in which statistics were available. The total manufacture and conversion also showed a great decrease. As all the information necessary was not in, the board was still unable to give a full report. This shows that the situation in 1935 regarding statistics was still about as it was in 1929.

Under the Genera Convention, it wa.s the board's duty to watch continuously the course of international trade, and if it were found that excessive quantities of any substance covered by the convention were accumulating in any country,

1. C. 364. I. 185. 1935. XI., p. 14 
or that there was a danger of that country becoming a centre of the illicit traffic, the Board was empowered to take cartain steps to overcome the danger. The application of this conrention greatly reduced the amount of the illicit traffic. By studying consumption, export, import and seizure statistics, the board has been able to attack illicit traffic more direct1y. It was found that while tons of drugs passed into illicit traffic, reports showed but little. Import certificates were forged and no origin given for configcated goods. Clandestine factories were shown to exist in some countries, and illicit traffic was heary through the postal system and ship crews. Nany cases were called to the attention of the countries and in general there was a good spirit of cooperation, yet some countries honestly confessed that they could not handle the situation.

It was mostly through the study of the manufacture and trade statistics that the board got most of its information. Since compiling these figures on the illicit traffic and seizures, much was learned regarding the extent of the illicit traffic. New substances were manufactured that did not come under the conrention, and as the bringing of a new substance under its terms is a slow process, much could be menufactured in the meantime. The problem regarding manufactured drugs is much more satisfactory than that of raw opium. This is natural in that raw opium is produced 
in generally more backward countries.

The board has done good work with national administrations and was called to send a representative into some countries, Bulgaria for instance, to help organize their systems. The fact that government stocks were inaccurately kept in most countries constituted a major problem. Article 17 of the Iimitation Convention provides that manufacturers must submit to their goremments quarterly statistics, which shall include the percentage of alkaloids contained in the raw materials used. The government in turn must present to the Central Board annual summaries of the manufacturers' statistics. If this is carefully done by all gorernments, the board can have some accurate statistics upon which to base its reports.

The Iimitation Convention created what is known as the Supervisory Body to technically examine all statistics and alter them if necessary. This was a part of the measures of the Advisory Committee and presented to the Genera Conference in 1925 but it was struck out by the committee dealing with it. It was now seen that nothing definite could be accomplished without such power as this. In its work, if not actually, the supervisory Body is a complttee of the Central Board. The Limitation Convention further widened the powers of the board by requiring better prepared statistics and by covering more drugs. Also an 
explanation of the method of calculating the amount must accompany the report. 1

More power was also given by requiring that a notification be sent to the contracting parties when any country is exceeding its eatimates with regard to imports. All countries thereupon are to cease exporting to that country during the year in question, or until the board is satisfied that no further danger exists. If there seems to be a danger of any country's eatimate being exceeded, the export to any country not party to the convention of any consignment of drugs weighing more than $5 \mathrm{kgs}$. may bo stopped. 2 Such wide powers as these were not possible of acceptance by the Genera Conrention of 1925.

The Central Opium Board has been functioning since 1929. When reviewing its reports to the Assembly, we find that ito members are not hampered by national governments telling them what to do but more from lack of wider powera from properly constituted authority. True enough the Iimitation Convention adoed greatly to the prestige and power of the board and this was done mainly through an awakened public to the evils of the drug problem. When given still wider powers, the board will be more effective.

1. Limitation Conrention, Article 5, Paragrpah 3.

2. Ibid.. Article 14, Paragraph 1. 
"The Board has had a brief but active career. It has acquired data on drug consumption, showing how much and in what manner legitimate use of narcotics differed from country to country, and worked out a formula by which it may be possible to judge the medical needs of any country in spite of these differences. It has discovered that huge quantities of drugs have been consumed or collected in Japanese territories since 1929, and that comparatively large amounts of coca leaves are apparently used by latin people for making toxic wines. It has found that a large stock of coca leaves has accumulated in the Netherlands, and by calling attention to the fact has insured the Government responsibility for its control. The illicit traffic has been shown to distribute at least ten tons of drugs and hundreds of tons of opium among addicts each year, the chief victims being China, Egpt, and the United States, and some of the origins Turkey and Persia; sources of the traffic have been discovered in the manufacture of drugs not coming under the Geneva Convention, in the use of raw opium whose morphine content was not known, in the absence of control orer exports, and in the manufacture directly serving the illicit traffic. To meet these situations, Article II and 17 were included in the Iimitation Convention, and an attempt was made by the Board, though unsuccessfully, to secure power to take measures againat a government that did not control its exports. The general rolume, extent, and course of the legitimate production and trade in drugs has been regularized, so that departures from the normal are easily detected. It was found that in 1931 Sweden, Belgium, Yugoslavia, and Czechoslorakia began to manufacture morphine, and that Poland and Bulgaria intended soon to do the same. These have been, so far, the results of the Board's labours with statistics. Of less importance so far, but of very considerable significance, have been its activities in organizing national administrative units." I

I. Eisenlohr, I. E. S., International Narcotics Control, p.191. 


\section{CHAPIER VIII}

CONVENTION FOR ITMITING THE MANUFACTURE AND REGUIATING

THE DISTRIBUTION OF NARCOTIC DRUGS OF JUIY $13 \mathrm{TH}, 1931$ 


\section{CHAPTER VIII}

CONVENTION FOR IIMITING THE MANUPACTURE AND REGUIATING THE DISTRIBUTION OF NARCOTIC DRUGS OF JULY 13TH, 1931

The old problem of the limitation of the production of drugs had been presented many times in former conferences, but it was such a rash departure from present methods of attacking the situation that governments were skeptical about it. However, in 1929 the Assembly decided to attack the drug problem from this approach and it called for a draft to be made summoning a conference to consider the production of drugs. Some ardent enthusiasts endearoured to have the conference consider the suppression of poppy cultiration but in its final form it called for a consideration of a difficult and complex task of devising methods for bringing into effect the limitation of manufacture and regulation of the distribution of narcotic drugs. The Assembly has described this convention as embodying "a bold conception without precedent in the history of international relations and international law."I Bold though it may have been, still this conference did not go as far toward limiting production as was desired by many.

The conference called grew out of former meetings and

1. A. 51. 1934. XI, p. 2 . 
conventions and was made possible by them. In 1912, or even in 1925, it would have been impossible to get the powers to agree to this exacting a conference. The former conventions paved the way towards this and future conferences and showed the world that more supervision was needed over the drug situation. International legislation was slow and had to be built up only as goremments were brought to see that alone they were powerless against the drug traffic. The first attack upon a problew rarely solves it but probably in no international problem has there been such speed in building up a satisfactory world law as there has been in regard to dangerous drugs. The First Hague Convention, covering only a limited area, occurred only nineteen years before the Iimitation Convention which operates in practically every part of the earth.

In dealing with the Iimitation Convention, as in dealing with any international body, we must bear in mind that it was not drawn up by a permanent organization. Although we have had the Advisory Committee working on the drug situation since 1920, its personnel has changed many times. The continuity of membership has been lacking and thus corporate traditions have not been present. The Iimitation Convention was building up international law that was pioneering on new ground. It was trying to deal with a worldwide situation and that in itself presented seemingly impregnable barriers. 
The general purpose of international conventions has been to secure the application of their principles on as uniform lines as possible in the various countries of the world. This purpose has been aided greatly by the League's drawing up model administrative codes to the International Opium Conventions of 1925 and $1931 .{ }^{1}$ These codes are suggested models for the countries to pattern after in forming their own national drug regulations and from this method there has resulted a more uniform application of the conventions.

The task of the Iimitation Conference was a difficult one. Up to 1931 there had been a great decrease in the consumption of narcotics. It was agreed that there was still too much illicit drugs on the market and that this manufacture should be limited. Farlier conferences had confirmed the fact that wholesale trade, export and manufacture itself pave the way to a great use beyond the legitimate requirements of most countries. Also, the League had learned quite a bit about the drug situation since 1920. Through investigations and compilations of statistics it was fairly estimated that the world required in 1931 for its scientific and medical needs about forty tons of drugs and that these drugs were manufactured by about sixty licensed factories. Through

1, C. 774. M. 365. 1932. XI. 
further investigations, the League had a lnowledge of just what drugs were required in the medical profession and the extent of each drug needed by different countries. Since many ways of dealing with the drug situation had been tried, the success of these methods could be used in working out a plan to fit any opecial case. Efficient administration and supervision had already been found to be the beat methods of dealing with the illicit traffic since under this same system legally manufactured drugs had approximated or fallen below the actual requirements. Most of the arugs entering the illicit traffic were from clandestine factories. It can be seen from the knowledge already gleaned that there had been quite a bit of work done regarding the drug problem. With this information from which to begin, the Limitation Conference met under more favorable conditions than did any of its predecessors.

One of the main principles of the conference was the stressing of the idea that the drug situation was worldwide problem. Heretofore, drugs had been considered from the Far Fastern angle mostly and had not been dealt with in their true nature, that of a problem of the entire human race. The fact that more nations have signed this conrention than any previous one bears out the fact that it more nearly succeeded in showing the international scope of the drug dilemma. Many states not even parties to the conven- 
tion furnish statistios and ald in its work. This spirit of cooperation was not true under the former conventions. According to Article 30, the Iimitation Convention was to come into force when twenty-five states had deposited their ratifications. The required number was secured by July 9 th, 1933. The system put in force by this convention called for the establishment of a supervisory Body ${ }^{1}$ to estimate the drug requirements for the coming year for all countries and to circulate these estimates. Those countries having signed the convention were bound by the estimates, while those not signers were given an idea of their legitimate needs. Supervision over the drug traffic was to be by national as well as international bodies, and these two bodies were to work together in such a way that all drugs moving to authorized buyers from licensed factories would be known about by one or both of these bodies. Thus, any cargo taken over by an authority could immediately be determined if legal or illegal. Also, there was to be an international audit of the drug accounts of each nation and the Central Board would check to see if any nation had exceeded its year's estimate previously prepared by this same board. This plan represents the first attempt so far made by the concerted action of the governments of the world, from the point at which the raw materials

1. Advisory Committee, Central Board, and office International d'Hygiene publique each to appoint one member. 
enter the factory to the point at which they finally reach the legitimate consumer. Under the convention, no contracting party may manufacture, export, or import dangerous drugs without accounting for such transections, and without its whole drug situation being supervised by an international body. The conference tried by international agreement to limit the manufacture of dangerous drugs to the legitimate requirements as worked out by the Supervisory Body. It should be understood that the convention formed at this time deals only with manufacture while another one to be held later is to deal with the problem of production.

Naturally this convention can be enforced only against signatories but the Supervisory Body may make out estimates for countries not members, and who send in no estimates, in order to figure the world's legitimate requirements. Each estimate must show four things, namely,

1. The quantity necessary for medical and scientific needs.

2. The amount secured for conversion into derivatives.

3. The omount of reserve stock.

4. The quantity necessary for establishing and mainteining government reserve stock.

Since all countries naturally would not calculate their estimates alike, all such estimates, to be examined by the Supervisory Body, must be accomparied by a statement showing 
the method used.

Some countries may manufacture too much in any one year, if 80 the excess is to be decuoted from the estimate prepared for the next year. All drugs designated to be converted must be converted in the period specified, otherwise there might be an accumulation of arugs in a country which could not be accurately accounted for. If any country signing the convention has an excess stock present, this stock must at once be confiscated for government reserve. This measure was taken so that all known drugs would be under the supervision of the government from the time the first estimate was made.

The vital necessity in getting accurate figures on the drugs used in each country is the bringing of every new drug, that can be termed dangerous, under the scope of the conventions. This can be done only by having some competent body determine the characteristics of any new drug. Since this was the prevailing opinion at the Iimitation Conference, it was decided that the Health Committee of the League would be the most appropriate international body to examine and report on such drugs.

At the end of each year, statistics showing the consumption, conversion, manufacture, imports, exports, and estimates given beforehand of all drugs coming under the convention are to be prepared by the board for each country. 
Such procedure will enable the League to see the drug situation in each country from all angles except the illicit traffic, which is hard to estimate with any degree of accuracy. Regardlese of how good or bad the results agreed upon by any conference may be, another prime necessity is the providing for an agency to make these results effective. Fully realizing this failure in former drug conventions, it was now provided that all parties signatory to this convention should set up national administrations to see that the measures were carried out. All phases of the drug problem were to be strictly supervised with the parties notifying the secretariat of the League if manufactured drugs were for internal use or export. The discovery of any illicit operations were to be likewise reported and these in turn sent by the secretariat to any other country that might be affected by such operations.

Thus it was agreed upon that the foregoing measures would make for an effective limitation of manufacture, since these regulations were the most adranced that any conrention had attempted to set forth. The interesting point is that al though this convention far surpassed its predecessors in giving effectireness to 1 ts measures, still it had secured, up to 1938, the greatest number (sixty-four) of ratifications of any convention concluded under the auspices of the League. Still more important is the fact that the Supervisory Body, 
set up by the Iimitation Conrention, recelved for the 1938 statement reports from sixty-three countries and 104 territories and had only to make estimates for ten countries and two territories. ${ }^{1}$ such cooperation, which had not been enjoyed under any other convention, coupled with the fact that this convention embodied the most adranced international administration yet adopted, certainly gives hope to the world that the drug problem may soon be b rought under control. 
CFAPTER IX

CONAISSION OF ELQUIRY INTO THE CONTROI OF OPIUN

SMOKING IN THE FAR RAST 


\section{CHAPTER IX}

COMMISSION OF ENQUIRY INTO THE CONTROL OF OPIUM SMOKING IN THE FAR FAST

The movement for the suppression of the opium traffic began without any basis upon which to eraluate the actual work of the League in this mission. No accurate data was present and it was only through commissions of enquiry into different phases of the problem that any tangible information could be secured. Many of the discussions centered about the Far East, 80 in 1928 Great Britain drew the attention of the Council of the Ieague to the fact that the effort to suppresa the smuggling of opium had failed in those territories of the Far East in which opium smoking was still permitted. She further emphasized that the prospects of undertaking the gradual and complete suppression of the use of prepared opium had receded indefinitely. The British memorandum was referred to the Assembly which thereby recommended that the Council appoint a commission of three persons to conduct the enquiry proposed by the British Government but not to restrict their activities to the Far East. lany phases of the opium situation were to be investigated by this commission of enquiry. Much oplum was prepared for smoking and it was necessary to determine the extent to which this was used and the main territories in which 
this indulgence was mainly present. Certain obligations had been assumed by the Hague Opium Convention of 1912 and the Genera Opium Agreement of 1925 but as yet the League did not know what measures had been taken by the governments of the Far East to give effect to these obligations. Ho doubt many difficulties existed, especially the illicit traffic, to prevent the fulfillment of the obligations undertaken by the countries, but the extent and nature of this illicit trafic and its relation to laws of the nations was vague even to the delegates to the League from these countries concerned. After a thorough investigation of the entire situation, the commission was to evaluate its information and to suggest what action should in the circumstances, be taken by the governments concemed and by the League of Nations. ${ }^{1}$

Apparently a rather detailed and earnest study was made in the three years this commission spent in visiting eleren territories. The conclusion reached was that the gradual and effective suppression of opium smoking would require concerted action on similar and concurrent lines by all governments concerned in the Far Eastern problem. In view of this conclusion, the commission's suggestions were sent to all of the Far Eastern governments and to those governments having colonies or territories in this area.

1. c. 635 . X. 254. 1930, XI., p. 10 . 
The actions suggested should be based on international cooperation, covering all the aspects of the opium-smoking problem. It is interesting to note that practically all enquiries and committees urged internationalizing the opium problem at this period,while prior to 1912, and very little immediately after, it was virtually impossible to get this idea accepted by the governments. The league was now urged to use all its efforts to help the countries reach agreements on the lines suggested and carry out such agreements in cooperation with each other. The Ieague should, moreover, follow closely the situation as regards opium control for the purpose of insuring progress and the final suppression of opium-smoking in all territories. Wany measures for the suppression of the habit of opiumsmoking were found but there had been no coordination of these messures, the resulting conditions being a disregard for the laws because of their ineffectireness. An international scientific research campaign regarding the drug problem was very essential as scientific knowledge is an indispensable factor in this situation and such knowledge be disseminated to all parts of the world. This ides was not new but it added weight to the proposition and many nations are now conducting very valuable studies. Several reports have been made to the League of the researah conduoted at the United States Narcotic Farm at Iexington, Kentucky and this, when deemed valuable enough, has been sent to all nations needing 
similar information.

The commission found further that merely nationalizing the growth of the poppy plant would never terminate the opium problem but that international steps should be taken to limit and control this cultivation. The accuracy of this statement has been proved in China. When she made her big effort to free herself of the drug menace, just prior and during the World War, her greatest handicap was foreign opium findings its way into the illicit Chinese market. Since the raising of poppies is an agricultural problem and the revenue derived therefrom aided the poorer classes, it was found imperative that other products should be developed and encouraged by the governments to take the place of the poppy plant. China used cereals fairly successfully for a period and other countries might profit by doing the same.

The social and hygienic conditions were shown to be at a very low ebb and needed great improvements otherwise opium would be indispensable to them. The best procedure suggested was an organized public opinion and propaganda conducted through reading material coupled with the educational system, sports and physical education to show the dire evil effects of opium smoking. The end in view would naturally be to suppress the use of opium except as a medical or scientific product. Such campaigns have been used in regard to other conditions and it seemed logical that if the public 
could be made to realize the situation as it existed there would probably be an awakening and strengthening of forces opposing the eril.

Another recommendation of the commission of enquiry was a single intelligence bureau in each territory to prevent illicit traffic. Not only should this bureau be established, but it should have attached to it the necessary machinery to make it effective, such as fast launches and automobiles to catch the traffickers. When caught, these traffickers should have imposed upon them such severe penalties that they would sense that the governments were active in their campaigns. It was shown that in many instances penalties were too light and also that fines or imprisonment differed greatly in the countries investigated when the some offense was committed. This defect would be remedied by the international control of the traffic as suggested. When illegal supplies of opium were found, it was nearly an impossibility to track down the source of it but this could be remedied by mixing government opium, which would be the only legal opium according to the commission's recommendations, with some secret substance so that when detected it could be analyzed and determined if government or illicit opium. This would narrow down the souroe and thus enable the agents of the government to concentrate on lllicit factories or smuggling activities. To make smuggling unprofitable, 
government opium should be sold low enough so that smugglers would be incapable of withstanding repeated losses by the preventive measures. The principle of making oplum a luxury should not, however, be overlooked if smuggling ceased to be a danger. The control of the international trade should necessarily conform strictly to all international obligations of that territory or country with which trading was conducted. Just as force is a necessary corollary to law in domestic society, so force must become a necessary part of any national administration of the opium problem. The accuracy of this statement was recognized by the commission in recommending a government opium monopoly for the retail distribution, all shops, licensing and control to be definitely in the hands of govermment offlcials. All amokers were to be contacted by the government as soon as possible and all transactions connected with the distribution of oplum to smokers were to be government functions. There should be adopted into the law the principle of medical certificates being the only basis for the issuance of a license to smoke opium. Under such a system as here recomended, a, country, if in earnest, could certainly go forward in its control of the opium problem and aid its people greatly by gradually stamping out the evil.

It is possible to attain real security, the entire suppression of the use of opium beyond medical and scientific 
needs, only by attacking every phase of the problem. One of best measures brought forth by the commission was for the increased and systematic attention to the cure of opium addiction. If prevention could be applied to the production of opium and a cure effected for opiate addicts, then the problem would be narrowed down to the illicit traffic. The governments, supported by the medical profession, should take the lead in the plan for helping these people and the money necessary should be taken from the opium revenue. This would thus attack the problem on two fronts, getting all revenue possible from the illicit traffic and using this to help those mainly affected by this traffic.

The proof of any scheme is in the actual working of it. This commission made a valuable study and report but opium production and addiction havenever been solved. In 1938 a Foreign Policy Report ${ }^{l}$ stated that the center of the illicit traffic is in China and Manchukuo and that the section north and south of the Great Wall yields $90 \%$ of the raw opium of the world. We can't blame this on the commission but we can give them oredit for their report and say that much of the information it gave was used as a basis for discussion in the Limitation Convention of 1931. This commission had no power to make any reforms but merely to make a survey and report and to this end it accomplished its purpose.

1. Merrill, F. T., "The Opium Menace in the Far East", Foreign Policy Report, 12:294-304, Mr. 1, 1937. 


\section{CHAPTER X}

PREPARATICNS TOR A IIMITATION OF PRODUCTION CONFERENCE 


\section{CHAPTER $X$}

PREPARATIONS FOR A IIMITATION OF PRODUCTION CONHERENCE

The great necessity in narcotics control, and especially opium, if the reduction of the cultivation of raw materials. Before any effective control of manufacture can be accomplished, there must be a limiting of the production of the raw materials. since there has been a tightening of drug manufacture by the application of the Iimitation Convention of 1931, the illicit factories have found their ways to places where actual control is less. Ilkewise, the same result will be found regarding the raw material unless there can be some definite control put on all producing areas.

The scheme for limiting production of dangerous drugs, especially opium, has been considered in many international conferences, but the task has always seemed too large for the countries concerned. Yet it is only common sense to see that all former conventions were useless unless the source of the supply of dangerous drugs could be checked. With this thought in mind, the Assembly of the League petitioned the Advisory Committee to draw up plans for such a convention. In accordance with the petition, the committee, at its twenty-third session (1938) sent a report to the Council "Concerning the Preparatory Work for a Conference to consider the possibility of limiting and controlling the cultivation of the Opium Poppy and the Production of Raw Opium."I 
In this draft the Advisory Committee framed a definite statement of the main principles which should serve as a basis for the future convention, including ways of determining world requirements in raw opium and a method of adapting the production of raw opium to these needs.

The Adrisory Committee in 1936 had appointed a Preparatory Committee to work out the draft for this convention. The report of this comittee formed the basis for the discussion at the twenty-third session. Certein objects or motires had to be formulated before it could be shown that a Iimitation of Production Convention was necessary. It has already been shown in previous chapters that there was a great quantity of illicit opium and other drugs available for use. Thio great quantity of drugs had naturally come from an overproduction of manufacture, and the manufacture in turn had been made possible by the overproduction of raw opium or other raw drugs. This was especially emphasized by the Preparatory Committee and, inasmuch as the Convention of 1931 had limited the legal manufacture of arugs, it seemed evident that the only hopes of limiting illicit manufacture was to limit production of raw drugs. This one condition has been the main cause of much clandestine manufacture.

When the Governments of Western Europe made such strict laws regarding manufacture of drugs, the illicit 
factories gradually moved to the Near Fast and Far Fast and were thus closer to the supply of the raw material. Only by atriking at the root of the eviz can the manufacture of these clandestine factories be checked.

In addition the copium smoking problem was greatly increased in those countries burdened with the evil by the illicit trade in raw and prepared opium. This was noted by the Geneva Conferencos in 1924 and 1925. Since opium was produced in such excessire quantities beyond the world requirements, much of it entered into illicit trade. A statement of this nature was the main conclusion of the Commission of Enquiry into the Smoking of Opium in the Far East in 1931. This Comission stated that as long as the opium poppy was grown unrestricted there would always be the problem of illicit traffic. Such conditions as these led the League to ask the Adrisory Committee to plan for a Limitation of Production Conference if the interested countries would agree.

The Preparatory Committee decided that the objectives of the proposed conference were:

1. To suppress the abuse of narcotic drugs;

2. To supplement the Hague Convention of 1912, the Genera Convention of 1925 and the Narcotics Limitation Convention of 1931."1

1. C. 221. M. 123. 1938. XI., p. 13. 
The substance to be corered by this convention are poppies cultirated for the production of raw opium and raw opium itself. These items are to be subject to certain measures of control if the poppy plant is used for the extraction of opium alkaloids or if the plant is cultivated for other purposes. The opium produced is to be what is needed for medical and scientific requirements except that non-medical uses present in certain countries might be continued if legal under former conventions.

Certain methods of achieving limitation are suggested in the draft. Each country must send in its estimated requirements and each year's estimate must be taken care of during that year. In addition, none orer this estimate is to be imported. All governments which produce opium are to send in the estimates of their production for the year and include with this the method used for calculation. Some international controlling authority shall examine these estimates, and shall have the power to give to each producing country, on the basis of the estimates, the yearly amounts to be produced and exported. Realizing that any excess of drugs would cause a problem, the committee favored not sowing more area any year than that which is necessary to meet the quotas given by the authority nor to export more then that amount given for exporting. All existing stocks of raw opium shall gradually be reduced over a period of years and 
then kept at a level to the needs for annual requirements. The international body supervising this convention shall be assisted by national control for carrying into force all clauses contained in the convention.

The recognized world requi rements

"of raw opium are determined by the amounts of this raw material needed for the manufacture of druga, medicinal opium, extracts and tinctures, for the manufacture of prepared opium and for internal nonmedical consumption (e.g.,eating)."1

The aim of the convention is to reduce this supply of raw opium to the actual needs, and thus reduce the use of prepared opium.

The powers and duties of the controlling body that will determine the amounts for each country will naturally have to be delegated after the system of limitation has been adopted. One system suggested is the quota system, under which, a fraction set in advance, of the world requirement, would be allotted to each country. Under another system, the free order system, each country sending in requirements would state what country they wished to buy from, but this system is criticized as making an indefinite area of cultivation for each year. Under either system the controlling agency will allot to the producing countries definite production and export quotas.

1. C. 221. H. 123. 1938, XI. p. 16. 
It was agreed that this future convention could not be a success unless all countries, or at least all producing and exporting countries, adhered to it. Turkey and Yugoslavia, through their representatives, made it known that they would not support the plan unless it was adhered to by all important producing countries. The suggestion was made that countries that had not hitherto produced opium should not do so in the future, but as nature, climate and cost of labor limit the area of opium production, this suggestion did not seem important.

As stated above, this is the draft for a conference to be held in the near future. The need of such a conference is evident, but many changes may be made in the draft before it becomes effective. There is no doubt a great need for a limitation of production and such has been recognized by every former conference. Much discussion along this line has taken place and many good arguments favoring such a plan have been given. The revenue side of the picture is always kept in the background but the arguments given by certain delegations give evidence to the fact that finances determine policies. For the sake of humanity, this conference should do what none of its predecessors have done, namely, strike a death blow to the very heart of the drug evil, the production of raw opium. 
CHAPTER XI

GENERAI SUMATARY AND CONCLUSIONS 


\section{CHAPTER XI}

\section{GENERAL SUMMARY AND CONCLUSIONS}

The international movement to control the commerce in opium and other dangerous drugs has come a long way in the last twenty-fire years. In no other field are governments making a similar attempt to control an article of commerce. The fact that the success or failure of this movement will have profound effects upon other phases of our economic life gives the drug problem a new significance. Viewed as a whole, the history of the drug problem presents many dark sides but likewise more encouraging ones.

There was a movement in some quarters in England against opium in the first part of the twentieth century, but the United States became the leader shortly after the acquisition of the Philippines in 1898. The first instance of international dealing with the opium problem, coming largely as a result of American initiative, resulted in the Shanghai Conference of 1909. After reading the proceedings of that conference, one wonders that so much has actually been accomplished up to 1939. Financial and political greed were so rampant in 1909 that no formal convention was obtained, but the meeting led to the calling of the First Hague Conference in 1912.

By 1912 the nations interested in the drug problem 
were beginning to realize that public opinion was frowning upon the evil and expecting something to be accomplishod by this conference. So, very reluctantly, the nations gave up a small amount of their control orer drugs. The pages of the conference reveal repeatedly the playing of commercial against humanitarian interests but with at least the final acknowledgement that the narcotics problem was international in scope.

The convention finally formed in 1912 was so cumbersome that two additional conferences in 1913 and 1914 were required before there was enough acceptance to put the convention in force. Then the mighty catastrophe of the World War enveloped practically every country that had signed the convention and the narcotics problem seemed the least of their worries. Actually there was a slipping backwards in the methods of dealing with drugs during tris period and the emergence of peace in 1918 found the problem in more dire need of solution than ever before.

Then one of the bright rays of hope for humanity arose out of the dark clouds of war. Thanks to those who look beyond the mere spoils of war, reference was made to the Hague Convention in the Versailles Treaty so that the signatories of the treaty automatically became parties to the convention. Thus in one stroke there was a greater adherence to the Hague Convention in a few short weeks than there had 
been in the six previous years.

The general supervision of the drug problem was entrusted to the League of Nations, created by the Versailles Treaty, by the Covenant of the League. Forthwith, at its first session, the League constituted an "Advisory Committee on the Traffic in Opium and other Dangerous Drugs." Ever since 1912 there had been the idea of a permanent international body to supervise the drug traffic but the creation of the Advisory Committee was the first such attempt. The discussion and national feeling that arose in the appointing of this comittee showed clearly that many nations felt that national sovereignty was at stake. The committee was created amid dissension and there was much "ambiguity as to its duties and competence." At first it was composed of twelve members from manufacturing countries plus three assessors who were to possess special knowledge of the drug problem. In 1931 seren additional members were appointed from non-manufacturing countries. The views of the comittee immediately began to assume different proportions. There is still much criticism that the committee is too large and has too many members from manufacturing countries. The appointment of the Advisory Committee was a great step forward, but it has never accomplished much. Too much nationalism has been shown ano too narrow an interpretation of its powers has been adhered to. It has pared the way for newer and better controls of the narcotics problem and has given some 
valuable aid in getting information for the study of the problem.

The Council of the League, at the behest of the Advisory Committee, called for two conferences to be held in 1925 to strengthen the Hague Convention of 1912 and effect final agreement as to the manufacture and production of dangerous drugs. These conferences were held without their relation to each other clearly defined. France and the United States opposed the two conference idea in vain. The First Conference was to report its results to the League and not to the second Conference. The dissension that followed greatly handicapped the conference in its work.

The First Conference adopted an agreement atrengthening the Hague Convention by providing that the importation, manufacture, and distribution of opium should be made a state monopoly, with certain exceptions, by prohibiting the sale of opium to minors, and by various other measures. This was entirely unsatisfactory to those nations that had hoped to see an agreement reached that would call for the suppression of the smoking of opium within a specified, reasonable time. When China saw that no definite undertaking was to be assumed by the conference, she withdrew because she would not allow financial considerations to influence her opium policies. China had urged that all profits be used to aid those who were affected by the drug 
evil but the other powers refused.

The Second Conference was called two weeks after the first one. Results of some value were achieved in regard to the control of the international traffic in narcotic drugs, yet these results were mere facts and did not call for the creation of an international body for effective - control. The Permanent Central Opium Board was probably the outstanding creation of the Second Conference. It showed that a need existed for an international control agency but there was still enough nationalism present to prevent a great deal of power being rested in the board. This board has functioned in a larger measure than the Advisory Committee and has completed some valuable work. It marks the beginning of effective control of the drug problem but it must have still wider powers to achieve a real supervision of the situation.

The United States had sent delegates in an "unofficial capacity" to the Second Conference. Not being able to get the American ideas incorporated in the conference, the American delegation withdrew. No doubt there was much political rivalry and commercial greed shown at this meeting, but the American delegation could have attained more prestige by forcing the issue with the other nations. There was much criticism following their withdrawal. It was very unfortunate that out of forty-one delegations that took part in the conference, only fourteen remained and signed the con- 
vention. Opium was left at about the same place it was before the conference.

The conference for limiting the Manufacture and regulating the Distribution of Narcotic Drugs in 1931 added to the prestige of the Central Board by creating the Supervisory Body. This body has the power to examine estimates of countries and p repare estimates to be considered by those who fail to send them in. As intended, this body would have had vastly more powers, but when finally created, it had to accept that which the sovereign states were willing to grant. The Conventions of 1912, 1925 and 1931 show the gradual tendency of governments to transfer certain powers once considered sovereign to international control. This shows a great advance in the drug problem but it leaves it far from solution.

The Assembly of the Ieague has proposed a conference for the limitation of raw opium, the preliminary committees of which met in 1938. Many students of the drug problem have believed for years that this is the only effective way to control the situation. The source is the main thing, yet the conferences have been blindly trying to control the use instead of eliminating this source. Of course we can always see the financial views of many of the delegations in these conferences and their fear of losing national powers or rights. 
Regarded as a whole the drug situation is far from settled. We should marvel at what has been done because of the great handicaps the League has encountered. But on the other hand, those nations that have been so selfish as to let humanity ouffer for financial reasons should hide their faces in shame. Not always has this been given as the reason, but after a careful study of the question it seems that this factor is most instrumental in the fallure of states to surrender the drug problem completely to a competent international authority.

The idea that the manufacture of drugs should be restricted to medical and scientific needs has been adopted. But getting proper cooperation in putting this principle into effect is entirely a different story. After admitting the validity of this rule, nations have constantly refused to give adequate authority to any controlling agency. International supervision has been strengthened but it has never been given a chance to function in such a way as to have actual control. In some phases of the problem England has shown rather a selfish attitude. India is a great producer of opium and a great deal of her revenue in the past has come from this commodity; therefore, Britain in many instances has blocked suppressive movements. Furthermore the opium wars of the nineteenth century with China have ever since been blots on the English record; yet several Engliah organizations have 
done valuable work in the anti-narcotics field.

Japan likewise may be criticized. China did a great work in suppressing opium smoking up to 1917 but immediately thereafter the trade was reopened. China has since tried to control the evil but since the Sino-Japanese conflict began in 1931, the use of opium has spread to the territory occupied by Japan. Gavit says "all northern China has been of late years an open sewer-end for Japan's illicit drug distribution; to that is to be added now the government-aided production of raw opium." The Japanese claim a fine military control of their territories so if this is true we must believe that they do not want to suppess the drug evil. The vice at least could be supervised if Japan wanted to do so.

The most effective suggestion for the control of the drug problem is the system of monopoly control. This would be accomplished through national and international monopoly with a high degree of cooperation at all times. All phases of the problem from the production to the use of the finished product would be supervised. How soon, if ever, nations will agree to this is not known at the present time, but certainly we can have hope when most nations are at least admitting that this is the best method. There no doubt will be a great struggle before such a system is effected. For centuries the evil of drug production and use had gone virtually untouched until the moderm era awakened to its dire effects. Now in a few short years, compared with the long 
period of no control, a great movement has been launched to rid the world of the drug. Methods have been tried until monopoly seems the only answer. The question before humanity today is, will nations awaken from their lethargy and put under control the enormous problem of narcotic drugs? Probably no arug known to medicine is more important than opium and its derivatives; but uncontrollet, as it has been in most of our past history, it can certainly have very derastating effects upon those who are so weak as to come under its powers.

Today many are asking if the League of Nations will continue. No one knows the answer to this question. Regardless of the operation of the League in trying to settle disputes between nations, it seems evident that the social and humanitarian work will continue. Japan has now been out of the League for some time, but she continues to be a member of the Advisory Committee and had a representative present at the last meeting in 1938. This goes to show that there is a feeling, even among the totalitarian states, that such work as this must continue.

We have had the drug problem with us since Biblical days and it does not seem that it will disappear from the international scene at any early period. Many appaliing facts have been presented, but now that they are realized they should be remedied. If the coming conferences are 
a little more faithful to the ideals of humanity than the past conferences have been we shell be going toward the fulfillment of one of the destinies of the world; but if the coming conferences are a little less faithful to these ideals, then we shall be headed toward greater disasters in the drug problem. For the benefit of those millions who suffer from the use of narcotic drugs, it is our hope that these conferences will meet the problem with understanding and courage. 


\section{BIBLIOGRAPHY}

\section{BOOKS}

Bell and Woodhead, The China Yearbook, 1912, New York, E. P. Dutton and Co., I912.

Bishop, Frmest $C_{.}$, The Narcotic Drug Problem, New York, The Macmilian Co., 1921.

Dixon, G. Graham, Truth About Indian Opium, London, His Majesty's stationery Office, 1922.

Eisenlohr, I. E. S., International Narcotics Control, Iondon, George Allen and Unwin Itd., 1934.

Gavit, John Palmer, Opium, London, George Rutledge and Sons, Itd. 1925.

Lamotte, Ellen N., The Opium Monopoly, New York, The Macmilian Co.. 1920.

Morse, H. B., The International Relationg of the Chinese Empire, London, Longman 8 , Green and co.. 1910.

Owen, David Edward, British Ooium Policy in China and India, New Haven, Yale University Press, 1934.

Walpole, Spenser, History of England, Vol. VI, London, Longman's, Green and Co.

Williams, Edward $\mathrm{H}_{0}$, Opiate Addiction - Its Handling and Treatment, New York, The lacmilian Co.. 1922.

Willoughby, W. W., Opium as an International Problem, Baltimore, The John Hopkins Press, 1925.

Woods, Arthur, Dangerous Drugs - The World Fight Against Illicit Traficic In NarcoticB, New Haven, Yalo University Press, 1931.

U. S. Statutes at Large, Volumes $35,38,40$ and 42.

\section{FHCYCLOPEDIA ARTICLES}

, "Opium", Encyclopedia Britannica, 


\author{
BIBLIOGRAPHY
}

IFAGUE OF TATIONS DOCUMENTS

Minutes of the First (etc.) Session of the Council, Genera, $1920-38$.

Records of the First (etc.) Assembly, Plenary Meetings, leetings of the Committees, Genera, 1920-38.

Report of the Advisory Committee on the Traffic in opium and Other Dangerous Drugs, First Tetc. T Session. Geneva, 1921-38.

Permanent Central Opium Board, Reports to the Council on the Work of the First (etc.) Seseion, Geneva, 1920-38.

International Opium Convention signed at the Hague, January 23, 1912, Geneva, 1923.

First Opium Conference, November 3,1924 - February 11, 1925, linutes and Annexes, Geneva, I925.

First Opium Conference, Agreement, Protocol, Final Act, Geneva, 1925.

Second Opium Conference, November 24 - December 3, 1924, Plenary leetings, Meetings of the Committees and Sub-Committees. In two volumes, Genera, 1925.

Second Opium Conference, Convention, Protocol, Final Act, Geneva, 1925.

Records of the Conference for the Iimitation of the Manufacture of Narcotic Drugs, May 22 to JuIy 13,1931 . Geneva, 1931.

Convention for Limiting the Manufacture and Regulating the Distribution of Narcotic Drugg, Geneva, 1931.

Conference on the Suppression of Opium Smoking, Bangkok, November 9 - 27, 1931. Kinutes of the meetings and documents submitted to the Conference, Geneva, I932.

List of Illicit Transactions and Selzures reported to the League of Nations since November 6th, 1929, Geneva, 1930. 
Conference on the Suppression of Opium Smoking, Agreement and Final Act, Genera, 1932.

Commisgion of Enquiry into the Control of Opium-Smoking in the Far East, Report to the Council, Geneva, 1930.

Commission of Enquiry into the Production of Opium in Persia, Report to the council. Geneva, 1926.

Analysis of the International Trade in Morphine, Diacetylmornhine, and cocaine for the years 1925 - 30 , Geneva, $19 \overline{30}$

Control of Narcotic Drugs in Turkey, Memorandum forwarded by the Minister for Foreign Affeirs of the Turkish Republic, Geneva, 1931.

Conference for the Suppression of the Illicit Traffic in Dangerous Drugs, Convention, Protocol, Final Act, Geneva, 1936 .

Convention for limiting the Manufacture and regulating the Distribution of Narcotic Drugs of 1931. Historical and Technical study, Geneva, 1937 .

Annual Reports of Governments on the Traffic in Opium and other Dangeroug Drugg for the year 1936, Geneva, 1938.

\section{PERIODIGAIS}

Farnham, J. D. and Moorhead, H. H. , "International Iimitations of Dangeroug Drugs", Foreign Policy Reports, 19-37, April 1, 1931

Lester, Muriel, "The Blots on the National 'Scutcheon," Missionaxy Review," 59:79-82, February, 1936.

Hacht, David I., "The History of Opium," Scientific American, 350-52, May 29, 1915 .

Merril, F. T., "The Opium Menace in the Far East," Foreign Polioy Report, 12:294-304, March 1, 1937.

Moorhead, Helen H., "International Administration of Narcotic Drugs," 1928-34, Foreign Policy Report, Vol. X No. 26, February 27,1935 . 
Willoughby, W. W., "The Opium Conference - Why America and 1925

China Withdrew," Review of Reriews, 71:403-07, April,

Young, A. Morgan, "Japan's Way With the Vanquished," Living Age, 353:290-2, December, $193 \%$.

\section{Unsigned Articles}

"Why We Quit the Opium Conferen
Literary Digest, 84:8-9, February 21 , 1925 .

, "The League and the Opium Traffic," New Republic, 63-114, June 18, 1930.

January 1I, "Opium and Politics, "Time, 29:23-4,

"International Opium and Drug Conference," Political Science Quarterly, 41:20-2, March, 1926. March 4, I'́05.

"Opium and Human Nature," Outlook, 513-15, 